HOW DID THE RECESSION OF 2007-2009 AFFECT THE WEALTH AND RETIREMENT OF THE NEAR RETIREMENT AGE POPULATION IN THE HEALTH AND RETIREMENT STUDY?

\author{
Alan L. Gustman \\ Thomas L. Steinmeier \\ Nahid Tabatabai \\ Working Paper 17547 \\ http://www.nber.org/papers/w17547 \\ NATIONAL BUREAU OF ECONOMIC RESEARCH \\ 1050 Massachusetts Avenue \\ Cambridge, MA 02138 \\ October 2011
}

This work was supported by a grant from the Social Security Administration through the Michigan Retirement Research Center (Grant \# 5 RRC08098401-03-00). The findings and conclusions expressed are solely those of the authors and do not represent the views of the Social Security Administration, any agency of the Federal government, the Michigan Retirement Research Center or the NBER.

NBER working papers are circulated for discussion and comment purposes. They have not been peerreviewed or been subject to the review by the NBER Board of Directors that accompanies official NBER publications.

(C) 2011 by Alan L. Gustman, Thomas L. Steinmeier, and Nahid Tabatabai. All rights reserved. Short sections of text, not to exceed two paragraphs, may be quoted without explicit permission provided that full credit, including $(\mathcal{C}$ notice, is given to the source. 
How Did the Recession of 2007-2009 Affect the Wealth and Retirement of the Near Retirement Age Population in the Health and Retirement Study?

Alan L. Gustman, Thomas L. Steinmeier, and Nahid Tabatabai

NBER Working Paper No. 17547

October 2011

JEL No. D31,D91,E21,H55,I3,J14,J26,J32

\begin{abstract}
This paper uses asset and labor market data from the Health and Retirement Study (HRS) to investigate how the recent "Great Recession" has affected the wealth and retirement of those in the population who were just approaching retirement age at the beginning of the recession, a potentially vulnerable segment of the working age population. The retirement wealth held by those ages 53 to 58 before the onset of the recession in 2006 declined by a relatively modest 2.8 percentage points by 2010 . In more normal times, their wealth would have increased over these four years. Members of older cohorts accumulated an additional 5 percent of wealth over the same age span. To be sure, a part of their accumulation was the result of the upside of the housing bubble. The wealth holdings of poorer households were least affected by the recession. Relative losses are greatest for those who initially had the highest wealth when the recession began.
\end{abstract}

The adverse labor market effects of the Great Recession are more modest. Although there is an increase in unemployment, that increase is not mirrored in the rate of flow out of full-time work or partial retirement. All told, the retirement behavior of the Early Boomer cohort looks similar, at least so far, to the behavior observed for members of older cohorts at comparable ages.

Very few in the population nearing retirement age have experienced multiple adverse events. Although most of the loss in wealth is due to a fall in the net value of housing, because very few in this cohort have found their housing wealth under water, and housing is the one asset this cohort is not likely to cash in for another decade or two, there is time for their losses in housing wealth to recover.

Alan L. Gustman

Department of Economics

Dartmouth College

Hanover, NH 03755-3514

and NBER

ALAN.L.GUSTMAN@DARTMOUTH.EDU
Nahid Tabatabai

Department of Economics

Dartmouth College

Hanover, N.H. 03755

Nahid.Tabatabai@dartmouth.edu

Thomas L. Steinmeier

Department of Economics

Texas Tech University

Lubbock, TX 79409

thomas.steinmeier@ttu.edu 
This paper uses asset and labor market data from the Health and Retirement Study (HRS) to investigate how the recent "Great Recession" (officially December, 2007 through June, 2009) has affected the wealth and retirement of those in the population who were just approaching retirement age at the beginning of the recession. The subject of our analysis, the near-retirement population, would seem to be highly vulnerable to an unexpected downturn. They have very few effective options for adjusting their behavior in the face of the recession. They can postpone retirement and save at a higher rate. But postponing retirement is of less help to those who have lost their job. Moreover, there is little time to increase saving. So any large losses from the recession are likely to be permanent, affecting welfare throughout retirement.

There are four innovations in this paper that are the direct result of having HRS data available. First, the HRS provides panel data at the beginning and end of the recession allowing us to calculate changes in key outcomes for the same individuals over the full course of the recession. Second, HRS data enable us to compare the changes in outcomes between cohorts -- during the recession for those nearing retirement age at the onset of the recession, and over a comparable age span for members of older cohorts. Third we identify gainers and losers by their place in the wealth distribution. Fourth, speculation as to the likely effects of the recession on retirement most frequently focuses on measures of retirement expectations. In contrast, the HRS provides detailed data on actual retirement outcomes.

Our analysis measures wealth comprehensively, including the values of defined benefit and defined contribution pensions, Social Security, individual retirement accounts, the net value of housing and other accumulated financial and nonfinancial wealth. With these data, we measure the extent to which the recession's effects on volatile assets were cushioned by more stable assets.

Measures of employment related outcomes reported by the HRS include the extent of full-time work, partial retirement and full-retirement, hours of work, unemployment, as well as the number who 
report themselves as not retired but who also are not working. Flows among these states are measured over the four year period 2006 to 2010. The HRS data also allow us to understand what underlies changes in employment patterns and how conditions in the job market affected retirement flows. Thus involuntary layoffs are reported, as are other reasons leading to changes in employment status, including anticipation of a job loss. Enrollment in disability programs is also reported.

When we compare changes in outcomes by those exposed to the recession with the experience of older cohorts when they were the same age, there are a number of surprises. We see the near retirement age population experiencing only a 2.8 percentage point decline in wealth over the period of the Great Recession. In contrast, over the comparable age span, members of older cohorts enjoyed asset accumulations amounting to roughly five percent in real terms. Although the data suggest high rates of layoff during the Great Recession, members of older cohorts experienced layoffs at just slightly less than the rate observed over the recession. A great deal has been written about changes in retirement behavior induced by the recession. But this population on the cusp of retirement at the onset of the recession is retiring at roughly the same pace as did members of older cohorts at comparable ages. Finally, this cohort of households in their fifties is not frequently affected by multiple adverse events.

Section II reviews recent contributions to the literature documenting the effects of the recession. In Section III we measure the distribution of changes in the various components of wealth over a period spanning the recession. Section IV compares the changes in wealth experienced by the retirement age population exposed to the recession to the changes experienced by those from older cohorts as they passed through comparable ages. Gainers and losers are distinguished in Section V. Following that, Section VI examines changes in labor market outcomes, including the numbers falling into various labor market states, flows among those states including flows into retirement and reversals in retirement status, and reasons for changes in labor market status. Section VII concludes. 


\section{The Recent Literature}

Although the aftermath of the recession of 2007-2009 is still with us, a number of studies examining the effects of the "Great Recession" on older populations have already been completed. A first wave of studies used data from before the recession to predict its likely outcome on wealth and retirement. A later group of studies used data gathered during the recession to monitor its ongoing effects. More recently, some data from the period after the recession officially ended have become available.

In the context of a study of trends in wealth inequality, Wolff (2011) used 2007 data from the Survey of Consumer Finances. He projected the effects of the recession on wealth held by all households and by households age 47 to 64. Pension values, including values of both defined benefit and defined contribution plans, were calculated as of retirement age. Social Security wealth was estimated using earning functions rather than Social Security earnings histories. Wolff (p.38) concludes that between 2007 and 2009, "Among middle-aged households, mean pension wealth was down by 4.2 percent, mean net worth also by 4.2 percent and median net worth by 8.2 percent, while mean augmented wealth AW was down by 3.3 percent and median AW by 7.7 percent", where augmented wealth includes pensions and Social Security.

In other studies in the first wave of analyses examining the effects of the "Great Recession" on those approaching retirement age, the focus was on the how the sharp decline in the stock market would affect wealth and retirement. Some predicted that retirements would be deferred and the labor force participation of older workers increased. Thus Sass, Monk and Haverstick (2010) suggest: "The stock market crash of 2008 significantly dimmed the retirement prospects of those approaching retirement. These workers are heavily dependent on 401(k) plans, as opposed to traditional defined benefit pensions, as a source of retirement income." Similarly, Munnell, Muldoon and Sass (2009) concluded their 
discussion of the effects of the recession on retirement as follows: "With about two-thirds of their 401(k) portfolios invested in equities, older workers should recognize that the only way to compensate for their decimated assets is to remain in the workforce longer."

Others suggested the stock market decline would have smaller effects on the wealth and retirement of those approaching retirement age. Gustman, Steinmeier and Tabatabai (2010b) found that in 2006, the year preceding the recession, those in their early to mid fifties had only fifteen percent of their total wealth in stocks, including $401 \mathrm{k}$ plans and IRAs, so that even an initial stock market decline of one third would have a limited effect on their assets. Focusing on the effects of the decline in housing wealth, they found that most older workers had homes with limited mortgage obligations, so that even with a twenty percent decline in housing prices from values reported by respondents in 2006, $6.4 \%$ of the households approaching retirement age would find their home equity under water, with their home values exceeded by their mortgage obligations. They argued that the wealth of the retirement age population would only be affected in a limited way by the decline in the stock market and housing prices because Social Security and defined benefit pensions would cushion the effects of the recession on total wealth. ${ }^{2}$ When the modest effect of the stock market decline on the wealth of the retirement age population is considered together with previous estimates indicating that changes in stock market wealth have only limited effects on retirement (Gustman and Steinmeier, 2002), the stock market decline by itself might lead to an increase of the retirement age amounting only to a couple of months. Moreover, the majority of homes are not sold by older persons until one or another spouse becomes very ill or dies

\footnotetext{
${ }^{2}$ Social Security wealth is not entirely insensitive to the retirement date. If the recession induces earlier benefit claiming and reduces the number of years worked, then some years of earnings that would have been counted among the highest 35 years may be lost, reducing the Average Indexed Monthly Earnings (AIME) upon which Social Security benefits are based. In most cases, this effect is relatively small. There are other ways in which the recession may have a modest effect on benefits. Butrica, Johnson and Smith (2011) note that AIME is in part determined by the wage index used to inflate past earnings. Wage growth is lower in recessions, reducing the wage index used to raise past earnings to the year the covered individual reaches age 60 . Should the economy return to its previous path, this mechanism might not apply to younger workers. However, having a lower economy wide wage at age 60 will reduce the indexing of past earnings for those who were approaching retirement age at the onset of the recession.
} 
(Venti and Wise, 2004). As a result, those approaching retirement age at the onset of the recession have time for housing prices to recover before they are likely to sell.

When analyzing the effects of the recession on retirement, it is also necessary to consider the effects of layoffs. Again there is a first wave of studies that bases predictions on past behavior of retirement during recessions. By separating many individuals from long term employers, layoffs reduce the reward to work. Even if they could secure another job, most of those losing a long term job would experience a sharp decline in the offered wage. Wage reductions, costs of job search, relatively short time remaining in the labor market even for those who successfully locate a new job, all work toward encouraging earlier retirement by older persons who have been laid off (Stevens and Chan, 2001; Coile and Levine, 2009). Although older persons are less likely to experience a layoff given their greater tenure, those who are laid off have a lower probability of locating a new position at an acceptable wage (Chan and Huff Stevens, 2001; Johnson and Mommaerts, 2011). The combination of reduced pay for work and the extraordinary difficulty older workers have in securing a new job may lead many to simply give up and permanently exit the labor market.

Thus the question is whether the increase in work by older individuals induced by the loss of wealth suffered as a result of the recession exceeds or falls short of the reduction in work resulting from job loss and the decline in labor market opportunities facing older persons. On net, the recession might well increase, rather than reduce, retirements. This prediction is consistent with Coile and Levine's (2009) analyses of the relation of recessions to retirement observed in past years. (For a contrary view, see The Conference Board, 2011).

Following studies that used information gathered before the onset of the recession to predict its effects on retirement and wealth, the next wave of studies used data collected during the recession or just after it hit its trough. Some of these studies analyze the effects of the recession on wealth. Some report 
the incidence of unemployment, and the effects of the recession on retirement expectations. Typically these studies use data from Internet surveys or telephone surveys designed for quick turnaround. An extremely useful set of studies based on this approach has been conducted by Hurd and Rohwedder (2010). They trace the effects of the recession and its aftermath using data from Rand's high frequency internet survey. This survey, the American Life Panel (ALP), was administered quarterly in 2008-2009, with the quarterly survey supplemented by shorter monthly surveys thereafter. Chakrabarti, Lee, van der Klaauw and Zafar (2011) take a similar approach with internet data. (Rix, 2011) focus more on the respondents' perceptions of changes in their financial circumstances and their prospects should they retire, rather than documenting the exact size of losses by asset category.

More recently, a few studies use well known panel data sets to compare wealth outcomes before and during, or just after the recession. Bricker et al. (2011) use panel data from the 2007-2009 Survey of Consumer Finances to track changes in household financial status, finding a great deal of heterogeneity among households in how they have been affected by the recession.

Most studies of the effect of the recession on retirement typically focus on retirement expectations, rather than on actual retirement outcomes. ${ }^{3}$ Many of these studies find respondents expecting to delay their retirements by many months or years due to the recession. For example, Sass, Monk and Haverstick (2010) suggest there will be "A widespread rise in the expected age of retirement. About 40 percent expect to retire later than they had before the downturn - somewhat more than reported in earlier surveys - with most of those who intend to work longer delaying retirement by four or more years." Rix (2011) reports that older persons are expecting to work more by delaying exit from a full-time job, working part time, or by returning to the labor market after having left.

\footnotetext{
${ }^{3}$ See, for example, Hurd and Rohwedder (2010), Sass, Monk and Haverstic (2010), Chakrabarti, Lee, van der Klaauw and Zafar (2011), Rix (2011), Helman, Copeland and Vanderhei (2011) and The Conference Board (2011).
} 
In contrast, examining changes in retirement expectations in a multivariate setting, Helppie McFall (2011) finds a relatively small effect of wealth changes on expected retirement. Using data from the University of Michigan's web- and mail-based CogEcon survey and adopting a regression framework, she suggests that the average wealth loss from July 2008 to May/June 2009 was associated with a 2.5 month decline in expected retirement age.

Findings that use data from the Health and Retirement Study collected before and during the recession are just appearing. Goda, Shoven and Slavov (2011) use data from the 2006 and 2008 Health and Retirement Study. Their findings fall between those of Helppie McFall (2011) and the other studies of retirement expectations. On the one hand, they find the recession associated with a large increase in the expected probability of working full-time at ages 62 or 65 , or the expected retirement age. On the other hand, they conclude that the change in the stock market, attenuated by the change in unemployment, are together insufficient to explain the large increase in the expected date of retirement. ${ }^{4}$

Census data have recently been used to investigate the effects of the recession on retirement. Farber's (2011) analysis of data from the Displaced Worker Survey, a supplement to the Current Population Survey, suggests the recession may accelerate retirements. ${ }^{5}$ Farber uses these data to examine job loss and post displacement labor force status from 1984 through 2010. Job loss is extensive and unemployment duration is particularly long in the current recession. Reemployment rates are especially low when compared to other downturns over that period. Farber concludes that the consequences of job loss in the "Great Recession" have been unusually severe. He finds the adverse

\footnotetext{
${ }^{4}$ Goda, Shoven and Slavov (2011) use the reported date of interview and a geographic indicator as the bases for determining the level of the S\&P 500 index, housing prices and local unemployment. Interview date is taken to be exogenous to all relevant controls so that there is no effort to standardize for differences among individuals in wealth, housing and mortgage value, or the value of wealth held in the stock market. Note, however, that at least in the early waves of the HRS, there was some systematic relation between the interview date and household characteristics such as employment status and type of job. The existence of this relationship means that the date of the survey interview may not be an unbiased instrument for market and other economic conditions. That is, the survey date may be correlated with unmeasured characteristics of the individual or household.

${ }^{5}$ Basic descriptive statistics on the labor market experience of older persons during the "Great Recession" can be found in in Copeland (2011) and in Johnson and Park (2011).
} 
labor market effects of the current recession, including low reemployment rates, to be more severe both for all workers and for those aged 55 to 64 . Consistent with the self reports of older respondents indicating they will be postponing their retirement, in the current recession it is no longer the case that older job losers are more likely than younger job losers to leave the labor force. Moreover, older job losers are unlikely to leave the labor force despite the fact that they suffer a greater loss of specific human capital when they lose their job, and reemployed job losers ages 55 to 64 suffer greater wage losses than do members of other age groups. An obvious question is the influence of unemployment insurance in shaping this early finding.

Bosworth and Burtless (2011) analyze which factors are affecting Social Security benefit claiming and labor market micro and macro measures of labor force participation. As explanatory variables, they use time series data on returns to household wealth, including stocks, bonds and housing, and indicators of unemployment. They find labor market outcomes for men are not significantly related to changes in returns to wealth. Unemployment is associated with reduced labor force participation of older men over the age of 60, but not those 55 to 59 years of age. This study does not include information on the level or composition of household wealth. Nor are pensions included in their analysis. The bottom line is that their time series data indicate small or negligible effects of either changes in returns to wealth or labor market conditions on the labor market activity of those approaching retirement age.

An important question is whether and how retirement expectations and expected dates of benefit claiming diverge from actual dates of retirement or actual dates of claiming. Retirement expectations may be revised as new information arrives; an adverse labor market environment may prevent expectations from being realized; so may other unforeseen changes in own or spouse health, or other family circumstances. Hurd, Reti and Rohwedder (2009) argue that retirement expectations are 
predictive of actual retirement behavior. On the other hand, recent data suggest that despite expectations of delayed retirements, actual retirements may have increased after the onset of the recession. Importantly, for example, data from the Social Security Administration indicates that after the onset of the recession, benefit claiming at younger ages has increased. An increase in claiming at age 62 is consistent with the idea that the recession has accelerated, rather than delayed, retirements. Those who retire before normal retirement age are subject to an earnings test, and so are unlikely to be claiming their benefits early even though they continue working on their long term jobs. ${ }^{6}$ Thus claimants in their early 60s are more likely to come from the ranks of the retired and others out of the labor force rather than from those who continue to be employed. Consequently, it is important to look at the actual data on retirement and not just at retirement expectations.

In attempting to understand the effect of the recession on retirements, it is also important to bear in mind the trend in retirement. The data present a picture of a complex and changing retirement trend leading up to the recession. For example, a number of changes in Social Security and pension regulations reduced the penalty to delayed retirement. This in turn reduced retirements for those over age 65 (Gustman and Steinmeier, 2009a). Operating in the same direction, the increase in women's labor force participation and decline in the incidence and duration of interruptions to their employment spells has also been accompanied by an increase in women's retirement age. It is clear that the trend toward earlier retirement observed through most of the twentieth century was reversed after 1990. But it is possible that the trend to earlier retirement might once again reassert itself once the influence of onetime changes in retirement incentives and other factors work their way through. On the other hand, if the trend to delayed retirement is mainly driven by increases in life expectancy and the demography of the

\footnotetext{
${ }^{6}$ The penalty for early retirement is roughly actuarially fair, so early claiming of benefits does not affect Social Security wealth. However, early claiming does affect annual income over the remainder of the individual's life. In addition, early claiming may lead to lower incomes in retirement in the form of lower survivor benefits. For an analysis of the effects of recessions on early claiming and subsequent benefits, see Coile and Levine (2011).
} 
labor market, where retirement of the massive baby boom generation increases the demand for older workers, the trend is likely to continue. Uncertainty about the future course of the trend in retirement increases the difficulty of isolating the effects of the recession on labor market outcomes.

Importantly, studies using data from after the onset of the recession were able to document the incidence and likely consequences of multiple adverse events: including stock market losses, declines in home values amidst a frozen housing market and layoffs. Multiple adverse events mean, first of all, that many households would experience at least one type of loss. Hurd and Rohwedder (2010) found, for example, that between November 2008 and April 2010, 39 percent of all households experienced some type of financial stress, which included falling behind on the mortgage payment, having negative home equity, or having one or another spouse unemployed. The interaction of adverse events may magnify their negative consequences. For example, those who experienced a layoff and would normally have sold their homes and moved elsewhere could not do so without realizing a capital loss from selling their house. Those who sold their home to move to a new job could not ride out the decline in housing prices as someone who had not lost their job could. Nor could a homeowner who experienced a layoff relocate to a more favorable job market as readily as a renter who lost his job.

This review of the available literature highlights the many remaining uncertainties about the size and distribution of wealth and job losses due to the Great Recession. Given our special focus on the near retirement population, the availability of detailed information in the Health and Retirement Study that spans the recession and reports on these outcomes for those approaching retirement age at the onset of the recession is a welcome addition to our analytical arsenal. We now will apply these data to analyze how the Great Recession has affected this important segment of the population.

\section{Changes in Wealth Between 2006 and 2010 for the Near-Retirement Population}


We begin with a description of changes in household wealth spanning the period of the recession. The data on household wealth reported in Table 1 are from the Health and Retirement Study (HRS) for members of the Early Boomer cohort, those residing in households with at least one member age 53 to 58 in 2006. Respondents are included in the analysis only if they participated in the survey both in 2006 and 2010 and if their household structure remained unchanged over the intervening four years. Households reporting a wealth level that falls within the top or bottom 1 percent of households in the relevant year are excluded. Averages are reported in Table 1. Values for the median ten percent of wealth holding households are reported in Appendix Table 1A, while Appendix Table $1 \mathrm{~B}$ reports results for those in the bottom quartile of households ranked according to total wealth.

The components of wealth in 2006 are reported in current dollars in column 1 and in 2010 dollars in column 6. Wealth outcomes for 2010 are reported in current dollars in column 3. The basic elements of wealth include the present value of Social Security, the present value of pensions, disaggregated according to whether the plan is defined benefit or defined contribution, the value of the house net of mortgage debt, other real estate (primarily second homes), business assets, vehicles, financial assets (including direct stock holdings), and assets in Individual Retirement Accounts (IRAs). Appendix 1 describes the calculations of the components of wealth. ${ }^{7}$ Missing values are imputed using methods described in Appendix $1 .^{8}$

As seen in row 1, the last column of Table 1, when measured in 2010 dollars, the total wealth of the Early Boomer population is three percent (2.8 percent) lower in 2010 than it was in 2006. Thus the

\footnotetext{
${ }^{7}$ Calculations of the components of total wealth and comparable estimates for the median ten percent of wealth holding households and for the bottom quartile of wealth holding households are presented in Appendix Table 1. See Appendix 1 for a description of the calculations of the various components of wealth and for a description of the imputation procedure. Those falling in the top and bottom 1 percent of wealth holding households are excluded from the table.

${ }^{8}$ Imputations from Rand for 2010 wealth data were not available at the time we wrote this paper. Therefore, to put the imputed wealth amounts on the same footing for both 2006 and 2010, we have imputed missing asset values and values of assets when reports are confined to brackets. Our imputations for 2006 do not exactly match those in the Rand data, but there are no large or systematic differences. In later calculations where we report wealth changes for cohorts at comparable ages to the Early Boomers, we use wealth estimates from Rand for both years.
} 
cohort approaching retirement age has experienced a very modest reduction of total wealth as a result of the recession. A similar story is found for members of the median ten percent of wealth holding households. In Appendix Table 1A, when measured in constant dollars, the total wealth of the median ten percent of wealth holding households in 2010 is 4 percent (4.3 percent) lower than the wealth of the median ten percent of wealth holding households in 2006. The change in wealth for those in the bottom quartile of wealth holding households is even closer to zero. As seen in Table 1B, there is only a one percent decline between 2006 and 2010. 
Table 1: Components of Wealth in 2006 and 2010 For Households with at Least One Member Born from 1948 to 1953. Weighted.

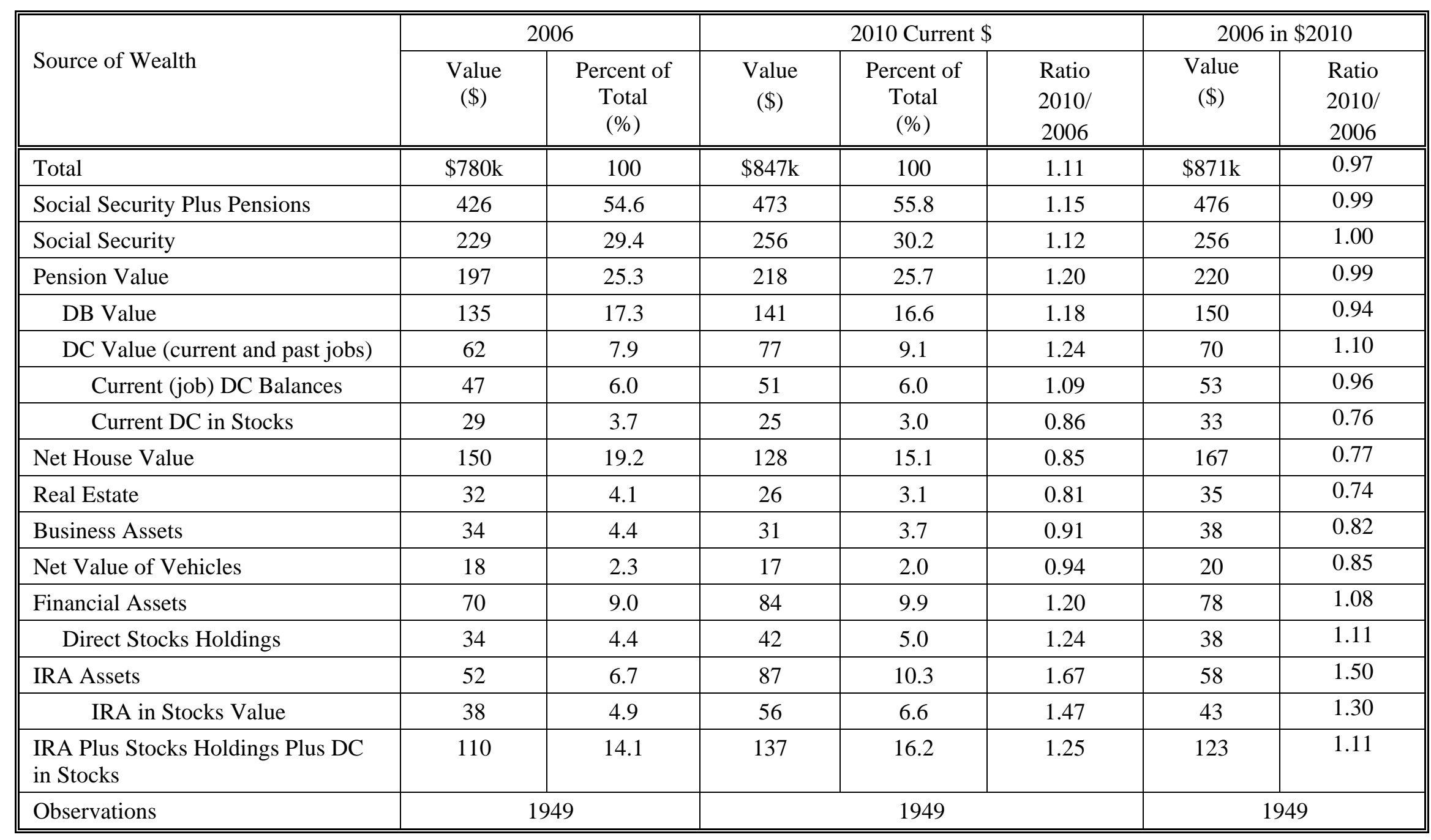


Now turn to the elements comprising total wealth in 2006. As seen in column 2 of Table 1, pensions and Social Security are the two most important assets. Together they accounted for 54.6 percent of total wealth in 2006. From Appendix Table A1, for the median ten percent of households arrayed according to total wealth, pensions and Social Security accounted for 64 percent of total wealth. For the bottom quartile of wealth holding households, pensions and Social Security accounted for 83.7 percent of total wealth. This reflects the well known result that Social Security accounts for a larger share of total wealth as we move down the wealth distribution, a relationship that is not fully offset by the increasing importance of pensions as we move up the distribution of wealth. For households in the Early Boomer cohort, on average Social Security accounts for 29.4 percent of household wealth. For households with median wealth, Social Security accounts for 43.9 percent of total wealth. For the bottom quartile of wealth holding households, Social Security accounts for 79.2 percent of total wealth. Roughly speaking, in 2006 pensions accounted for a quarter of total wealth at the mean, a fifth for median households, and for a tenth of total wealth for households in the bottom quartile.

The value of housing is the next largest component of total wealth. At the mean it accounted for 19.2 percent of total wealth in 2006. For median households, housing accounted for 21 percent of total wealth, while for those in the bottom quartile, housing accounted for 10.5 percent of total wealth.

Financial and IRA assets together accounted for 15.7 percent of total wealth at the mean. For median households, they accounted for 7.9 percent of total assets, while for those in the bottom quartile of wealth holding households, they did not contribute to total wealth, with a combined value of zero once debt is subtracted from assets held in checking, saving, DCs, bonds, treasury bills and other assets.

Consider next the changes in the components of total wealth reported between the 2006 and 2010 surveys. We examine these changes using constant 2010 dollars. Looking at the last column of row 3 of Table 1, by construction there is no change in the present value of Social Security. That is, we use 2010 
as the base period for calculating the present value of Social Security wealth no matter what the base year of the survey. ${ }^{9}$ Otherwise, we would find differences in total wealth between 2006 and 2010 simply because of the passage of time. ${ }^{10}$

A comparable approach is taken to calculating the present value of defined benefit pensions. In calculating DB wealth, 2010 is taken as the base period in which the present value is centered. From rows 4, 5 and 6 we see that the present value of pensions fell by about one percent in real terms between 2006 and 2010, with a six percent decline in the value of DB plans, and a ten percent increase in the value of DC plans. The value of DB wealth will be influenced by rollovers of DB plans into IRAs. The value of DC plans held in stocks fell by about a quarter, with assets in DC plans on current jobs falling by about 4 percent as some left their jobs. When this happens, DC wealth in plans from previous jobs are increased, partially negating any loss in total DC pension wealth. In addition, some DC plan balances were rolled into IRAs. Thus turnover in pension balances is also reflected in IRA assets reported in the fourth row from the bottom of the table. IRA assets are up fifty percent over the four year period.

There are four asset categories that suffered major declines in value over the recession: housing, real estate (mainly second homes), business assets and the net value of vehicles. Focus first on housing. Given that net housing wealth represented almost a fifth of total wealth, its decline is of greatest

\footnotetext{
${ }^{9}$ In all calculations we use a CPI increase of 2.8 percent per year and a nominal interest rate of 5.8 percent, approximations taken from the Report of the Board of Trustees of the Social Security Administration.

${ }^{10}$ Although it is reasonable to take the present values as of the survey date, and it is true that Social Security wealth is becoming more valuable as the individual approaches the age when benefits can be received, the aim of our exercise is to isolate the differences in wealth before and after the recession. Accordingly, we evaluate the wealth equivalent of income flows as of the same date even though the two periods are four years apart. Thus when we compare values in real 2010 dollars, there is no change in the value of Social Security wealth. To be sure, changes in earnings induced by the recession will affect the present value of Social Security benefits if earnings in later years change the average of lifetime earnings counted in the high 35 years of earnings that are used in the AIME (Average Indexed Monthly Earnings) calculation. We do not have Social Security earnings records for 2010 with which to calculate any resulting differences in PIA (Primary Insurance Amount). Past earnings are indexed through age 60, and most members of this cohort cannot change the years of earnings counted through early retirement age by changing claiming behavior. As noted previously, Butrica, Johnson and Smith (2011) point out, in computing average indexed monthly earnings, the wage index used to inflate past earnings is reduced for those who reach age 60 after the recession began. We do not make this adjustment.
} 
importance. In nominal terms, net housing wealth declined by 15 percent, while in real terms, housing wealth declined by 23 percent over the four year period. This is greater than the decline in housing prices because the relevant measure for a wealth calculation subtracts any mortgage obligation from the gross value of the house. Thus net housing wealth is more sensitive to the decline in housing prices than is gross housing wealth. The $\$ 39,000$ decline in real net housing wealth from $\$ 167,000$ to $\$ 128,000$ represents 4.5 percent of total wealth held at the onset of the recession. ${ }^{11}$ Thus the decline in housing wealth exceeds the entire decline in total wealth of households, and has absorbed some of the increase in total wealth that otherwise accrued from other assets.

As seen in Appendix Table 1C, we do not often see negative net housing wealth for members of the Early Boomer cohort. In 2006, 42 out of 1949 households had negative net housing wealth, averaging -\$81,716 in 2006. In 2010, 92 households had negative housing wealth, averaging -\$66,047 per household. Although this is a serious problem for those owning houses that are under water, and while the average gap is quite high for the affected households, only five percent of households in the Early Boomer cohort have negative housing wealth, even by 2010.

\footnotetext{
${ }^{11}$ On average the gross value of housing declined from $\$ 218,409$ in 2006 to $\$ 194,203$ in 2010, a decline of 11 percent. However, mortgage debt averaged \$68,862 in 2006 and \$66,319 in 2010, so that the \$24,000 decline in gross housing prices amounted to a 16.2 percent decline in nominal net housing wealth.
} 


\section{Comparing Wealth Changes from 2006 to 2010 with Changes Over Analogous Periods for Previous Cohorts}

Next we want to consider whether the changes in wealth for the Early Boomer cohort are consistent with those observed for earlier cohorts. Documenting differences over the same age span for members of earlier (older) cohorts, the War Babies ages 51 to 56 in 1998, and those HRS cohort members who were ages 51 to 56 in 1992, will increase our understanding of what part of the changes from 2006 to 2010 are due mainly to the recession. We are aware that differences in the path of wealth accumulation between members of the Early Boomer and older cohorts may reflect influences other than the recession, such as ongoing trends. Nevertheless, although not precise, we will find these comparisons to be quite informative.

To be more specific, before-after comparisons indicate that the total wealth of the Early Boomer population declined by 2.8 percentage points over the period of the Great Recession. The decline in housing prices reduced their total wealth by about 4.5 percentage points, so there was some net growth in the value of other assets. If we are to determine the full effects of the recession, we need some idea of how wealth would have grown in more stable economic times. Our findings indicate that wealth grew by 7.6 percent for the HRS cohort, and by 3.2 percentage points for the War Babies. With the two earlier cohorts enjoying average gains of 5.4 percentage points, the net wealth at the end of the Great Recession would have been about 8 percentage points higher had the Early Boomers' wealth grown at that same rate as seen for member of older cohorts.

The housing bubble played a role in increasing the growth of total wealth experienced by the older cohorts. Housing value grew by 38 percent between 2000 and 2004. In contrast, it fell 23.4 percent over the period of the Great Recession. More specifically, between 1994 and 1998, the growth in housing wealth accounted for 0.9 percentage points of the 7.6 percent increase in total wealth. For the 
War Babies, between 2000 and 2004 the growth in housing wealth increased total wealth by 5 percentage points, more than the 3.2 percentage point growth in total wealth. For the Early Boomers, the decline in housing value reduced total wealth by 4.5 percentage points, even though total wealth declined by only 2.8 percentage points in total.

In sum, even though this is by no means a formal analysis, it does suggest the Early Boomers experienced only a modest decline in total wealth over the period of the recession. They accumulated less wealth over the period of the recession than they would have were they members of cohorts born six or twelve years earlier, but a good part of that difference is due to the fact that members of the War Baby cohort enjoyed a wealth increase from the housing bubble. 
Table 2: Percent Changes in the Value of Components of Wealth For Members of Various HRS Cohorts Over the Period from the Second to Fourth Wave They Are in the Survey

\begin{tabular}{|c|c|c|c|c|c|c|}
\hline \multirow[b]{2}{*}{ Source of Wealth } & \multicolumn{3}{|c|}{ Current \$ } & \multicolumn{3}{|c|}{$2010 \$$} \\
\hline & $\begin{array}{c}\text { Original } \\
\text { HRS } \\
\text { Ratio } \\
1998 / \\
1994\end{array}$ & $\begin{array}{c}\text { War- } \\
\text { babies } \\
\text { Ratio } \\
2004 / \\
2000\end{array}$ & $\begin{array}{c}\text { Early } \\
\text { Boomers } \\
\text { Ratio } \\
2010 / \\
2006\end{array}$ & $\begin{array}{c}\text { Original } \\
\text { HRS } \\
\text { Ratio } \\
1998 / \\
1994\end{array}$ & $\begin{array}{c}\text { War- } \\
\text { babies } \\
\text { Ratio } \\
2004 / \\
2000\end{array}$ & $\begin{array}{c}\text { Early } \\
\text { Boomers } \\
\text { Ratio } \\
2010 / \\
2006\end{array}$ \\
\hline Total & 120.1 & 115.4 & 108.6 & 107.6 & 103.2 & 97.2 \\
\hline Social Security Plus Pensions & 114.4 & 106.3 & 111.0 & 102.2 & 95.4 & 99.4 \\
\hline Social Security & 111.1 & 111.6 & 111.8 & 100.0 & 100.0 & 100.0 \\
\hline Pension Value & 117.7 & 101.6 & 110.7 & 106.0 & 90.8 & 99.1 \\
\hline DB Value & 112.3 & 101.6 & 104.4 & 100.6 & 90.5 & 94.0 \\
\hline DC Value & 141.7 & 101.9 & 124.2 & 129.7 & 91.5 & 110.0 \\
\hline Current DC Balances & 131.6 & 0.87 & 108.5 & 113.3 & 80.0 & 96.2 \\
\hline Current DC in Stocks & - & - & 86.2 & - & - & 75.8 \\
\hline Net House Value & 118.8 & 154.1 & 85.3 & 106.5 & 138.7 & 76.6 \\
\hline Real Estate & 106.3 & 137.5 & 81.3 & 95.9 & 123.8 & 74.3 \\
\hline Business Assets & 110.0 & 111.5 & 91.2 & 96.8 & 97.1 & 81.6 \\
\hline Net Value of Vehicles & 100.0 & 106.3 & 94.4 & 91.3 & 105.0 & 85.0 \\
\hline Financial Assets & 141.5 & 116.0 & 120.0 & 126.5 & 104.7 & 107.7 \\
\hline Direct Stocks Holdings & 173.9 & 104.1 & 123.5 & 160.0 & 93.8 & 110.5 \\
\hline IRA Assets & 174.1 & 100.0 & 167.3 & 157.1 & 90.3 & 150.0 \\
\hline IRA in Stocks Value & - & - & 147.4 & - & - & 130.2 \\
\hline $\begin{array}{l}\text { IRA Plus Stocks Holdings } \\
\text { Plus DC in Stocks }\end{array}$ & - & - & 124.5 & - & - & 111.4 \\
\hline Observations & 3401 & 2028 & 1949 & 3401 & 2028 & 1949 \\
\hline
\end{tabular}




\section{Gainers and Losers}

In this section we distinguish those whose total wealth, as well as individual assets, gained or lost value over the period spanning the Great Recession. Table 3 reports the percentage of individuals experiencing changes in each of the components of wealth between 2006 and 2010, and the resulting changes in value. The value figures presented in Table 3 are different from those presented earlier in Table 1, where average values of assets held by all members of the cohort were reported for 2006 and 2010. Specifically, the earlier table included a value for an asset whether an individual held the asset or not, so that zero values were included for those in the population who did not report owning the asset. In contrast, asset values reported in Table 3 include values only for the subgroup of the population that actually owned the asset. ${ }^{12}$

Column 1 of Table 3 reports the share of Early Boomer households owning the indicated asset in 2006. Among the five most valuable assets from Table 1, 98 percent of households were eligible for future Social Security income, 71 percent had pension wealth, 79 percent owned a home, 66 percent had financial assets, and 43 percent had IRA balances.

The proportion of winning and losing households are reported in columns 2 through 5 . Losers and gainers are distinguished by whether their assets lost or gained value in terms of nominal or real dollars. Columns 2 and 4 list the proportions of households that enjoyed a loss or gain in the value of the indicated asset in terms of nominal dollars, while the proportions of households that enjoyed a loss or gain in real dollars are reported in columns 3 and 5. When assets are evaluated in 2010 dollars, from row 1, column 3, we see that 51.0 percent of households lost wealth between 2006 and 2010, while from row

\footnotetext{
${ }^{12}$ Another difference between the samples included in Tables 1 and 3 should be noted. Households are excluded from the sample in Table 1 if they fall in top or the bottom one percent of wealth holding households in 2006 when 2006 wealth levels are reported, and in 2010 when 2010 wealth levels are reported. Households are excluded from Table 3 if they fall in the top one percent of wealth holding households in 2006 or in 2010. This accounts for the slight difference in number of households included in each table.
} 
1, column 5, 48.3 percent of households gained wealth. When those assets are evaluated, from the last column of row 1, the total value of assets held fell by 2.6 percent between 2006 and $2010 .^{13}$

Turning now to the major asset categories, with the exception of Social Security wealth, which is held constant in real terms by construction, the number of households experiencing a loss in value for each major asset type is greater than the number of households where the asset gained in value. Comparing the numbers of households falling in columns 3 and 5, 53 percent of households experienced a loss in pension value, while 44 percent experienced a gain. The remainder experienced no change. In terms of housing wealth, losing households outnumbered gainers by 69 percent to 30 percent. Similarly, 63 percent of households experienced a loss in financial assets vs. 37 percent who experienced a gain. The one asset category where gainers outnumbered losers was IRA assets, where 47 percent of households reported a decline in the value of their IRAs in real terms, while 54 percent reported a gain.

The last column of Table 3, starting with row 2 down, reports the changes in the real value of each individual asset among households who had a positive value for the asset in both 2006 and $2010 .{ }^{14}$ Net housing value declined by a quarter for those households owning their home in both periods. Moreover, real estate (mainly second homes), business assets and the net value of vehicles declined in value. But the other major asset categories showed a gain, and the gains were almost large enough to offset the loss in net housing wealth and in other losing categories. Pensions rose in real value by 1.2 percent; financial assets increased by 3.5 percent, and IRA assets gained 40.2 percent. The gain in IRA assets most certainly reflects the effects of rollovers. Note, however, that with the real pension wealth

\footnotetext{
${ }^{13}$ A word of warning is in order as we move from overall averages to statistics on losers and gainers. Wealth numbers are reported with significant error. Moreover, some respondents may neglect to report an asset in one survey while reporting it in another. When changes are estimated, the gain or loss for an individual who neglected to report the asset in one year or another will be equal to the full amount of the asset. Finally, assets are imputed separately in each year of the survey. Imputations based on cross section data will create very large gains or losses when the same household is not used to impute the missing asset, or asset bracket, in both years.

${ }^{14}$ Again, these numbers differ from those reported in Table 1, which included all households, including those that did not hold the asset in question in 2006 and thus had a zero value for the asset. The HRS data provides information on total assets as reported in Table 1, but does not allow us to trace specific transactions, either sales or purchases of particular assets. We do not know the offsets in the accounts used to finance the changes.
} 
increase of 1.2 percentage points between the two years, the increase in the values of pensions due to contributions and additional work was sufficient to offset the loss in pension value to rollovers. DB values grow in part because DB pension wealth on current jobs is prorated by the ratio of tenure to date divided by tenure by the time the individual reaches expected retirement age. For DC plans, balances grow with contributions over the intervening years, as well as real interest and other payments. 
Table 3: Changes in the Number of Households Holding Each Component of Wealth and in the Value of the Component, 2006 to 2010

\begin{tabular}{|c|c|c|c|c|c|c|c|c|}
\hline & \multirow{3}{*}{$\begin{array}{c}\text { Percent } \\
\text { With } \\
\text { Indi- } \\
\text { cated } \\
\text { Com- } \\
\text { ponent } \\
\text { of } \\
\text { Wealth } \\
\text { in } 2006\end{array}$} & \multicolumn{4}{|c|}{ Conditional on Having Component of Wealth in 2006} & \multirow{3}{*}{$\begin{array}{l}\text { Value in } \\
2010 \\
\text { Condi- } \\
\text { tional on } \\
\text { Having } \\
\text { Com- } \\
\text { ponent } \\
\text { of } \\
\text { Wealth } \\
\text { in } 2006 \\
\& 2010\end{array}$} & \multicolumn{2}{|c|}{$\begin{array}{c}\text { Percent Change in } \\
\text { Value, } 2006 \text { to 2010, } \\
\text { Conditional on } \\
\text { Having Component } \\
\text { of Wealth in } 2006 \text { \& } \\
2010\end{array}$} \\
\hline & & \multicolumn{2}{|c|}{$\begin{array}{l}\text { Percent Experiencing } \\
\text { Decline in Value in }\end{array}$} & \multicolumn{2}{|c|}{$\begin{array}{l}\text { Percent Experiencing } \\
\text { Increase in Value in }\end{array}$} & & \multirow[t]{2}{*}{$\begin{array}{l}\text { Current } \\
\text { Dollars }\end{array}$} & \multirow{2}{*}{$\begin{array}{c}\text { Con- } \\
\text { stant } \\
2010 \\
\text { Dollars }\end{array}$} \\
\hline & & $\begin{array}{l}\text { Current } \\
\text { Dollars } \\
\text { (\% obs.) }\end{array}$ & $\begin{array}{c}\text { Constant } \\
\text { Dollars } \\
\text { (\% obs.) }\end{array}$ & $\begin{array}{l}\text { Current } \\
\text { Dollars } \\
\text { (\% obs.) }\end{array}$ & $\begin{array}{c}\text { Constant } \\
\text { Dollars } \\
\text { (\% obs.) }\end{array}$ & & & \\
\hline Total & 99.8 & 34.9 & 51.0 & 65.1 & 48.3 & $\$ 842 \mathrm{k}$ & 8.8 & -2.6 \\
\hline Social Security & 98.0 & 0 & 0 & 100 & 0 & 261 & 11.7 & 0 \\
\hline Pension & 71.1 & 43.4 & 53.4 & 56.5 & 43.6 & 328 & 13.0 & 1.2 \\
\hline DB Pension & 50.0 & 65.3 & 71.8 & 34.7 & 28.2 & 314 & 11.6 & -0.1 \\
\hline DC Pension & 49.7 & 38.8 & 43.2 & 60.6 & 45.3 & 162 & 19.0 & 6.6 \\
\hline Net House Value & 79.3 & 59.1 & 69.4 & 36.2 & 30.4 & 157 & -15.6 & -24.5 \\
\hline Real Estate & 15.3 & 74.0 & 77.2 & 23.1 & 22.8 & 214 & -5.6 & -15.5 \\
\hline Business Assets & 11.8 & 68.5 & 74.1 & 25.9 & 25.9 & 345 & 5.7 & -5.4 \\
\hline Net Value of Vehicles & 86.2 & 53.9 & 61.7 & 39.7 & 38.3 & 20 & -6.6 & -16.4 \\
\hline Financial Assets & 65.8 & 59.8 & 63.2 & 39.6 & 36.8 & 151 & 15.6 & 3.5 \\
\hline Direct Stock Holdings & 25.6 & 67.8 & 73.6 & 27.6 & 26.4 & 194 & 20.3 & 7.8 \\
\hline IRA Assets & 43.3 & 42.5 & 46.5 & 57.0 & 53.5 & 216 & 56.5 & 40.2 \\
\hline IRA in Stocks Value & 35.5 & 50.9 & 54.2 & 48.7 & 45.8 & 161 & 30.1 & 16.5 \\
\hline Total Observations & & & & & & & & \\
\hline
\end{tabular}

Households with top and bottom 1\% of total wealth in 2006 and 2010 are excluded from this table. 
Table 3A describes the distribution of losers among households ordered by their wealth. Results are described for the ten deciles of wealth holding households, with the wealth decile in 2006 indicated in the first column of the Table. The second column of the table reports the average level of wealth in 2006 for the members of the indicated wealth decile.

Column 3 reports the ratio of total wealth held in 2010 to total wealth held in 2006 by members of each wealth decile, where again the order is determined by level of total wealth in 2006. From column 4 of Table 3A, 39 percent of households in the lowest wealth decile experience a decline in the value of their assets. This rises to 70 percent of the households in the highest wealth decile. Thus as wealth increases, a smaller proportion of households experiences a gain and a larger share experience a loss. Two reasons for this may be mentioned. First, the sources of wealth held by those in the lowest wealth decile are likely to be much less vulnerable to the recession than are the sources of wealth held by those in the top deciles. Comparing Table 1 with Appendix Table 1B, members of the lower quartile of wealth holding households are much less likely to own a house, to have stocks or bonds, or to have pensions. Indeed, 79 percent of the wealth held by members of the lowest wealth decile is due to Social Security wealth. Second, measurement errors, especially errors of omission in the 2006 wealth data, are likely to play an important role in affecting the ratio of wealth in 2010 to 2006 by wealth decile. These errors are especially likely to cause an understatement of the share of households in the lower decile who lose wealth as a result of the recession. Households that actually have higher levels of wealth but fail to report or understate the value of one or more major assets are much more likely to fall in the lowest wealth decile in 2006. While it may not be common to fail to report having a house, the financially knowledgeable respondent may confuse the net and gross value of a house. If the expected sale price net of the mortgage is reported as the gross value of the house, the value of the house will be substantially understated. An error like that may not be repeated in 2010. Thus if there was an understatement of asset 
values in 2006, and that understatement is not repeated in 2010, the household will have been placed in too low a wealth decile in 2006, and will also exhibit a large gain in assets between 2006 and 2010.

The next five columns of Table 3A report additional information on the relation between the size of the asset decline and initial wealth. Thus from row 1, column 5, 19 percent of households in the lowest wealth decile experience a loss of 0 to 10 percent of total wealth, but 6 percent of households experience a loss of more than half their total wealth. In contrast, 12 percent of households in the highest wealth decile experience a loss of 0 to 10 percent, and another 13 percent experience a loss of more than half their assets.

Table 3B reports the distribution of households gaining wealth between 2006 and 2010 by the amount of wealth gained. The share of households experiencing a gain in assets at first increases with initial wealth, but from the fifth to tenth decile the share experiencing a gain declines with wealth. Forty nine percent of households falling in the lowest wealth decile in 2006 experience a gain in wealth over the period of the recession, while thirty percent of households falling in the top wealth decile experience a gain. 
Table 3A: Distribution of Households Experiencing a Decline in Real Wealth Between 2006 and 2010 by Wealth Decile in 2006

\begin{tabular}{|c|c|c|c|c|c|c|c|c|}
\hline \multirow[b]{2}{*}{ Deciles } & \multirow[b]{2}{*}{$\begin{array}{l}\text { Level of } \\
\text { Wealth } \\
2006\end{array}$} & \multirow[b]{2}{*}{$\begin{array}{l}\text { Ratio } \\
\text { 2010/2006 }\end{array}$} & \multirow{2}{*}{$\begin{array}{l}\% \\
\text { Experiencing } \\
\text { a Decline }\end{array}$} & \multicolumn{5}{|c|}{ Declines } \\
\hline & & & & $\begin{array}{l}\% \\
\text { Exper- } \\
\text { iencing } \\
0-10 \%\end{array}$ & $\begin{array}{l}\% \\
\text { Exper- } \\
\text { iencing } \\
10-20 \%\end{array}$ & $\begin{array}{l}\% \\
\text { Exper- } \\
\text { iencing } \\
20-30 \%\end{array}$ & $\begin{array}{l}\% \\
\text { Exper- } \\
\text { iencing } \\
30-50 \%\end{array}$ & $\begin{array}{l}\% \\
\text { Exper- } \\
\text { iencing } \\
>50 \%\end{array}$ \\
\hline 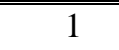 & 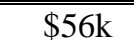 & 1.46 & 0.39 & 0.19 & 0.06 & 0.03 & 0.03 & 0.06 \\
\hline 2 & 150 & 1.39 & 0.39 & 0.26 & 0.06 & 0.02 & 0.03 & 0.02 \\
\hline 3 & 256 & 1.17 & 0.45 & 0.15 & 0.11 & 0.05 & 0.08 & 0.06 \\
\hline 4 & 392 & 1.08 & 0.54 & 0.15 & 0.15 & 0.08 & 0.10 & 0.05 \\
\hline 5 & 520 & 1.13 & 0.46 & 0.21 & 0.09 & 0.07 & 0.08 & 0.02 \\
\hline 6 & 661 & 1.04 & 0.56 & 0.12 & 0.13 & 0.11 & 0.12 & 0.07 \\
\hline 7 & 858 & 1.11 & 0.54 & 0.15 & 0.11 & 0.09 & 0.12 & 0.07 \\
\hline 8 & 1,097 & 1.10 & 0.52 & 0.15 & 0.13 & 0.07 & 0.13 & 0.04 \\
\hline 9 & 1,492 & 0.91 & 0.68 & 0.16 & 0.16 & 0.14 & 0.10 & 0.12 \\
\hline 10 & 2,524 & 0.82 & 0.70 & 0.12 & 0.11 & 0.15 & 0.20 & 0.13 \\
\hline Total & 865 & & & & & & & \\
\hline
\end{tabular}

The highest and lowest 1 percent of wealth holding households in either 2006 or 2010 have been eliminated from the sample. 
Table 3B: Distribution of Households Experiencing an Increase in Real Wealth Between 2006 and 2010 by Wealth Decile in 2006

\begin{tabular}{|c|c|c|c|c|c|c|}
\hline \multirow{2}{*}{ Deciles } & \multirow{2}{*}{$\begin{array}{l}\% \\
\text { Experiencing } \\
\text { an Increase }\end{array}$} & \multicolumn{5}{|c|}{ Increases } \\
\hline & & $\begin{array}{l}\text { \% Exper- } \\
\text { iencing } \\
0-10 \%\end{array}$ & $\begin{array}{l}\text { \% Exper- } \\
\text { iencing } \\
10-20 \%\end{array}$ & $\begin{array}{l}\text { \% Exper- } \\
\text { iencing } \\
20-30 \%\end{array}$ & $\begin{array}{l}\% \text { Exper- } \\
\text { iencing } \\
30-50 \%\end{array}$ & $\begin{array}{l}\text { \% Exper- } \\
\text { iencing } \\
>50 \%\end{array}$ \\
\hline $\bar{~} 1$ & 0.49 & 0.22 & 0.04 & 0.05 & 0.06 & 0.19 \\
\hline 2 & 0.59 & 0.20 & 0.12 & 0.06 & 0.08 & 0.16 \\
\hline 3 & 0.54 & 0.21 & 0.10 & 0.03 & 0.06 & 0.15 \\
\hline 4 & 0.46 & 0.13 & 0.08 & 0.06 & 0.07 & 0.12 \\
\hline 5 & 0.54 & 0.17 & 0.10 & 0.06 & 0.08 & 0.14 \\
\hline 6 & 0.45 & 0.11 & 0.08 & 0.07 & 0.09 & 0.09 \\
\hline 7 & 0.46 & 0.09 & 0.09 & 0.08 & 0.07 & 0.13 \\
\hline 8 & 0.49 & 0.17 & 0.07 & 0.05 & 0.10 & 0.11 \\
\hline 9 & 0.32 & 0.11 & 0.07 & 0.05 & 0.04 & 0.05 \\
\hline 10 & 0.30 & 0.13 & 0.09 & 0.05 & 0.02 & 0.02 \\
\hline
\end{tabular}

Note that the highest and lowest 1 percent of wealth holding households in either 2006 or 2010 have been eliminated from the sample. 


\section{Retirement Outcomes}

We now turn to an analysis of retirement. The analysis begins with a discussion of retirement flows for members of the Early Boomer cohort over the period of the recession. Separate analyses are also presented for men and women. Next we compare retirements by members of the Early Boomer cohort over the course of the recession with retirements by members of older cohorts over the same age span. As noted in Section II, there are many reasons for the differences in the retirement behavior of members of different cohorts, so a simple comparison may not isolate the effects of the recession. Nevertheless, it is useful to consider the dynamics of retirement and how they compare between cohorts. Next we discuss the share of the population experiencing specific adverse labor market outcomes over the course of the recession, including layoffs and unemployment. These outcomes are again compared among members of different cohorts. Following that we calculate the share of the population from each cohort experiencing one or more of a list of adverse events, including changes in pension rules, foreclosure, job loss, or other adverse events.

\section{Retirement Within the Early Boomer Cohort}

Table 4 reports retirement flows between 2006 and 2010 for members of the Early Boomer cohort. Five states are analyzed: not retired, partially retired, completely retired, not relevant (a response to the retirement question that says the question is irrelevant because the individual does not work for pay, is a homemaker, etc.), and not working-not retired, a state that reflects either unemployment with active job search, or nonemployment, where the individual would be willing to accept a job, but does not engage in active search. Retirement status is measured by a combination of hours of work and self reported retirement status. The exact definition of each variable is reported under Table 4.

The row heads indicate status in 2006. Column heads report status in 2010. The numbers falling in the first five rows and first five columns report the share of those with the indicated status in 2006 flowing to the status indicated in the column head in 2010. For example, from row 1, among those not retired in 2006, 70 percent remained not retired in 2010, 7.1 percent partially retired, and 11.1 percent 
completely retired. Not relevant status in 2010 applied to only .2 percent of those who were not retired in 2006, and 11.7 percent of those who were not retired in 2006 reported themselves as not working but not retired in 2010.

From the row totals, row 1, column 6, 62.8 percent of the Early Boomer cohort were not retired in 2006. From the column totals, row 6, column 1, that fell to 49.2 percent in 2010 . Thus there was a considerable amount of exit from full-time work by this population as they aged from 53 to 58 in 2006 , to 57 to 62 in 2010. The share of the cohort partially retired remained relatively unchanged, increasing from 10.3 to 11.0 percent, while the percentage completely retired increased from 10.7 percent to 21.6 percent. The not working-not retired category, which should capture those who are involuntarily unemployed, along with others who may or may not have realistic job market expectations but claim to be available for work, increased from 10.0 percent of the cohort members in 2006 to 14.5 percent in 2010.

Notice the reversals in status. As seen in row 3, among those completely retired in 2006, 2.1 percent became not retired in 2010. Another 4.6 percent became partially retired. From row 2, among those partially retired in 2006, 28.3 percent were not retired in 2010.

Of course, none of these numbers, neither the shares of those falling in a given retirement outcome category in the base or final years spanning the recession, nor the flows among states, can tell us the effects of the recession on retirement outcomes or flows. We will attempt some simple comparisons among cohorts that may hint at the effects of the recession. Before turning to those comparisons, it is useful to discuss differences in retirement outcomes between men and women. 
Table 4: Retirement Flows from 2006 to 2010 for Early Boomers: Ages 53-58 in 2006. All (weighted)

\begin{tabular}{|c|c|c|c|c|c|c|}
\hline \multirow[b]{2}{*}{ Status in 2006} & \multicolumn{5}{|c|}{ Status in 2010} & \multirow[b]{2}{*}{$\begin{array}{l}\text { Row Total } \\
\text { Status in } \\
2006\end{array}$} \\
\hline & $\begin{array}{l}\text { Not } \\
\text { Retired }\end{array}$ & $\begin{array}{l}\text { Partially } \\
\text { Retired }\end{array}$ & $\begin{array}{l}\text { Completely } \\
\text { Retired }\end{array}$ & $\begin{array}{l}\text { Not } \\
\text { Relevant }\end{array}$ & $\begin{array}{l}\text { Not } \\
\text { Working- } \\
\text { Not } \\
\text { Retired } \\
\end{array}$ & \\
\hline Not Retired & 70.0 & 7.1 & 11.1 & 0.2 & 11.7 & 62.8 \\
\hline Partially Retired & 28.3 & 44.8 & 14.9 & 1.4 & 10.6 & 10.3 \\
\hline Completely Retired & 2.1 & 4.6 & 80.3 & 7.0 & 6.0 & 10.7 \\
\hline Not Relevant & 3.8 & 6.0 & 34.7 & 29.9 & 25.6 & 6.2 \\
\hline $\begin{array}{l}\text { Not Working- } \\
\text { Not Retired }\end{array}$ & 19.2 & 10.3 & 23.5 & 9.3 & 37.7 & 10.0 \\
\hline $\begin{array}{l}\text { Column Total } \\
\text { Status in } 2010\end{array}$ & 49.2 & 11.0 & 21.6 & 3.8 & 14.5 & 100 \\
\hline
\end{tabular}

Retirement status is calculated based on the number of hours worked per year and, in ambiguous cases, by self-reported retirement status as well. Respondents working at least 30 hours per week and 1560 hours or more per year are considered not retired. Respondents working less than 100 hours per year are considered not working. Those working at least 100 hours per year and 25 hours or less per week or less than 1560 hours per year are partially retired. If the number of hours per year worked is between 1250 and 1560, but the self-reported retirement status is either retired or not relevant, a partially retired status is assigned to the respondent. Respondents who report between 1250 and 1560 hours worked, but report not retired to the self-reported retirement status question, are considered to be not retired. Respondents who report not working to the self-reported labor market status question (J020) and respond not retired or partially retired to the retirement status question are considered to be not working and not retired. If they report not working in J020 and report themselves to be retired in the retirement status question, they are considered to be retired. If they report not working and not relevant in answer to the self-reported retirement status question, they are assigned to the "not relevant" category. 
Retirement of Men vs. Women

As is well documented in the literature, there are many differences in retirement states and flows between men and women. To illustrate these differences, Tables 4A and 4B disaggregate the data in Table 4, reporting retirement levels and flows separately for men and women.

The differences between men and women in the likelihood of falling within a given retirement category are obvious from these two tables. Women are less likely to have worked over their full lifetime and are more likely to retire at an earlier age when they do work. Proceeding down the last column of each table, while 72.0 percent of men were not retired in 2006, 54.4 percent of women were not retired. Thus despite recent trends in labor force participation of women and growing continuity of their time spent at work, women still exhibit lower full-time labor market activity. Consequently, men were less likely to be partially retired (6.8 percent vs. 13.5 percent), while men and women were equally likely to be fully retired (10.4 vs. 11.0 percent). Men were less likely to fall in the not relevant category (2.3 percent vs. 9.7 percent), which is characterized by no time at market work. Men were also less likely to be classified as not working and not retired (8.5 percent vs. 11.4 percent).

Consider next the retirement flows. Over the four year period from 2006 to 2010, the share of men in the cohort classified as not retired fell by 17.4 percentage points. For women, the decline in the proportion of cohort members not retired was 10.1 percent. For men, the fraction partially retired increased by 2.3 percentage points, while for women, the fraction partially retired declined by 0.8 percentage points. The share completely retiring was roughly the same for men and women. For men, 11.2 percent of the cohort completely retired over the period, while for women, the share completely retired increased by 10.6 percent. The increase in the fraction not working and not retired was slightly higher for men than for women. For men the increase in the share not working and not retired was 5.1 percentage points, while for women it was 3.8 percentage points. 
Table 4A: Retirement Flows from 2006 to 2010 for Early Boomers: Ages 53-58 in 2006. Males (weighted)

\begin{tabular}{|c|c|c|c|c|c|c|}
\hline \multirow[b]{2}{*}{ Status in 2006} & \multicolumn{5}{|c|}{ Status in 2010} & \multirow[b]{2}{*}{$\begin{array}{l}\text { Row Total } \\
\text { Status in } \\
2006\end{array}$} \\
\hline & $\begin{array}{l}\text { Not } \\
\text { Retired }\end{array}$ & $\begin{array}{l}\text { Partially } \\
\text { Retired }\end{array}$ & $\begin{array}{l}\text { Completely } \\
\text { Retired }\end{array}$ & $\begin{array}{l}\text { Not } \\
\text { Relevant }\end{array}$ & $\begin{array}{l}\text { Not } \\
\text { Working- } \\
\text { Not } \\
\text { Retired } \\
\end{array}$ & \\
\hline Not Retired & 71.0 & 6.8 & 11.0 & 0 & 11.1 & 72.0 \\
\hline Partially Retired & 26.0 & 45.1 & 18.4 & 0 & 10.5 & 6.8 \\
\hline Completely Retired & 2.0 & 5.2 & 81.1 & 3.1 & 8.6 & 10.4 \\
\hline Not Relevant & 2.1 & 2.1 & 56.3 & 26.1 & 13.5 & 2.3 \\
\hline $\begin{array}{l}\text { Not Working- } \\
\text { Not Retired }\end{array}$ & 16.7 & 6.3 & 31.3 & 3.0 & 42.8 & 8.5 \\
\hline $\begin{array}{l}\text { Column Total } \\
\text { Status in } 2010\end{array}$ & 54.6 & 9.1 & 21.6 & 1.2 & 13.6 & 100 \\
\hline
\end{tabular}


Table 4B: Retirement Flows from 2006 to 2010 for Early Boomers: Ages 53-58 in 2006. Females (weighted)

\begin{tabular}{|c|c|c|c|c|c|c|}
\hline \multirow[b]{2}{*}{ Status in 2006} & \multicolumn{5}{|c|}{ Status in 2010} & \multirow[b]{2}{*}{$\begin{array}{l}\text { Row Tota } \\
\text { Status in } \\
2006\end{array}$} \\
\hline & $\begin{array}{l}\text { Not } \\
\text { Retired }\end{array}$ & $\begin{array}{l}\text { Partially } \\
\text { Retired }\end{array}$ & $\begin{array}{l}\text { Completely } \\
\text { Retired }\end{array}$ & $\begin{array}{l}\text { Not } \\
\text { Relevant }\end{array}$ & $\begin{array}{l}\text { Not } \\
\text { Working- } \\
\text { Not } \\
\text { Retired } \\
\end{array}$ & \\
\hline Not Retired & 68.6 & 7.5 & 11.2 & 0.4 & 12.3 & 54.4 \\
\hline Partially Retired & 29.3 & 44.7 & 13.3 & 2.1 & 10.7 & 13.5 \\
\hline Completely Retired & 2.2 & 4.1 & 79.6 & 10.3 & 3.9 & 11.0 \\
\hline Not Relevant & 4.2 & 6.8 & 30.0 & 30.8 & 28.3 & 9.7 \\
\hline $\begin{array}{l}\text { Not Working- } \\
\text { Not Retired }\end{array}$ & 20.9 & 13.0 & 18.2 & 13.6 & 34.2 & 11.4 \\
\hline $\begin{array}{l}\text { Column Total } \\
\text { Status in } 2010\end{array}$ & 44.3 & 12.7 & 21.6 & 6.2 & 15.2 & 100 \\
\hline
\end{tabular}




\section{Differences in Retirement Flows Among Cohorts}

Once again, it is not enough to simply measure changes in labor market outcomes before and after the recession to determine how retirements were affected by the recession. Using HRS panel data for members of older cohorts, it is possible to determine whether there is a difference in outcomes between the members of the HRS Early Boomer cohort, whose retirement decisions were affected by the recession, and members of older cohorts, whose decisions were not. By observing the differences in retirement flows for members of each cohort, we can see the net effect of conflicting forces shaping retirement, such as the increase in retirement age resulting from the wealth effect from falling assets, and the acceleration in retirement due to the declining availability of suitable labor market opportunities. To be sure, as long as there are other forces at work differentially affecting the retirements of members of different cohorts, simple comparisons of labor market flows among members of different cohorts are only a useful first step.

To compare the differences in outcomes between cohorts, we examine comparable retirement flows to those reported for the Early Boomer cohort in Table 4. Table 4C reports retirement flows for the War Baby Cohort, ages 53 to 58 in 2000. In Table 4D we find the flows for members of the original HRS cohort who were ages 53 to 58 in 1994.

By way of background, the unemployment rate in 1994 was 6.1 percent. It was 4.0 percent in 2000, and 4.6 percent in 2006. Thus the Early Boomers started out in a labor market with unemployment that fell between the unemployment rate experienced by members of the two older cohorts serving as comparison groups. Four years later, the unemployment rates were 4.5 percent in 1998, 5.5 percent in 2004, and 9.6 percent in 2010. The unemployment rate decreased by 1.6 percent for members of the original HRS cohort and increased by 1.5 percentage points when members of the War Baby cohort spanned the same age range. In contrast, reflecting the effect of the Great Recession, unemployment increased 5 percentage points over the period of observation for those in the Early Boomer cohort. 
Despite these wide differences in the initial levels and changes in the overall unemployment rate, the basic retirement flows look similar for members of the three cohorts. Comparing Tables 4, 4C and 4D, the percentage of Early Boomers not retired declined by 13.6 percentage points between 2006 and 2010. For the War Babies, the decline in the share of the population not retired was also 13.6 percentage points. For the HRS cohort, it was 10.6 percentage points. There were one or two percentage point changes in the share who are partially retired over each four year period. For the Early Boomers, the share partially retired increased by 0.7 percentage points over the four years. The comparable figures for the War Babies and HRS cohorts were 2.0 percentage points and 1.9 percentage points. ${ }^{15}$

The largest differences among the cohorts are in the changes in numbers not working and not retired. For the Early Boomers, there was an increase of 4.5 percentage points over the four years. For the War Babies, the increase was smaller, rising by 1.2 percentage points. For the members of the original HRS cohort, the share of the cohort not working and not retired fell over the comparable period by 7.2 percentage points. This is evidence of an adverse effect of the Great Recession on retirement flows.

\footnotetext{
${ }^{15}$ The option "not relevant" is based on different questions in different waves of the survey. Fortunately, the definition is consistent for the initial and final year used for any cohort, so changes in retirement flows within cohorts do not reflect the effect of a change in definition between the initial and final years examined. But the definition of the "not relevant" category asked of members of the HRS cohort in 1994 and 1998 is different from the question asked of the War Babies 2000 and 2004, or the Early Boomers in 2006 and 2010. In all six years, the respondent is asked if the retirement status question is irrelevant because the individual does not work for pay or is a homemaker. In 1992, however, the respondent is asked to choose the "not relevant" option if the individual had not worked for 10 years. In 1994 through 1998, those who had not worked for more than a year are asked to pick the "not relevant" category. From 2000 forward, rather than saying anything about how long the individual has not worked, after asking the same stem, the question simply says etc.
} 
Table 4C: Retirement Flows from 2000 to 2004 for War Babies: Ages 53-58 in 2000. All (weighted)

\begin{tabular}{|c|c|c|c|c|c|c|}
\hline \multirow[b]{2}{*}{ Status in 2000} & \multicolumn{5}{|c|}{ Status in 2004} & \multirow[b]{2}{*}{$\begin{array}{l}\text { Row Total } \\
\text { Status in } \\
2000\end{array}$} \\
\hline & $\begin{array}{l}\text { Not } \\
\text { Retired }\end{array}$ & $\begin{array}{l}\text { Partially } \\
\text { Retired }\end{array}$ & $\begin{array}{l}\text { Completely } \\
\text { Retired }\end{array}$ & $\begin{array}{l}\text { Not } \\
\text { Relevant }\end{array}$ & $\begin{array}{l}\text { Not } \\
\text { Working- } \\
\text { Not } \\
\text { Retired } \\
\end{array}$ & \\
\hline Not Retired & 72.2 & 8.6 & 11.2 & 1.7 & 6.2 & 65.3 \\
\hline Partially Retired & 23.6 & 43.2 & 16.5 & 5.8 & 10.9 & 9.4 \\
\hline Completely Retired & 4.8 & 5.3 & 69.2 & 15.4 & 5.4 & 7.8 \\
\hline Not Relevant & 3.2 & 4.9 & 30.5 & 47.4 & 13.9 & 10.0 \\
\hline $\begin{array}{l}\text { Not Working- } \\
\text { Not Retired }\end{array}$ & 20.8 & 11.0 & 26.8 & 17.0 & 24.4 & 7.5 \\
\hline $\begin{array}{l}\text { Column Total } \\
\text { Status in } 2004\end{array}$ & 51.7 & 11.4 & 19.3 & 8.9 & 8.7 & 100 \\
\hline
\end{tabular}


Table 4D: Retirement Flows from 1994 to 1998 for HRS: Ages 53-58 in 1994. All (weighted)

\begin{tabular}{|c|c|c|c|c|c|c|}
\hline \multirow[b]{2}{*}{ Status in 1994} & \multicolumn{5}{|c|}{ Status in 1998} & \multirow[b]{2}{*}{$\begin{array}{l}\text { Row Tota } \\
\text { Status in } \\
1994\end{array}$} \\
\hline & $\begin{array}{l}\text { Not } \\
\text { Retired }\end{array}$ & $\begin{array}{l}\text { Partially } \\
\text { Retired }\end{array}$ & $\begin{array}{l}\text { Completely } \\
\text { Retired }\end{array}$ & $\begin{array}{l}\text { Not } \\
\text { Relevant }\end{array}$ & $\begin{array}{l}\text { Not } \\
\text { Working- } \\
\text { Not } \\
\text { Retired }\end{array}$ & \\
\hline Not Retired & 74.5 & 6.8 & 10.4 & 3.5 & 4.8 & 61.2 \\
\hline Partially Retired & 24.0 & 47.3 & 9.6 & 106 & 8.6 & 8.9 \\
\hline Completely Retired & 3.4 & 4.3 & 53.5 & 33.9 & 5.0 & 10.2 \\
\hline Not Relevant & 3.1 & 5.0 & 18.2 & 65.1 & 8.6 & 6.0 \\
\hline $\begin{array}{l}\text { Not Working- } \\
\text { Not Retired }\end{array}$ & 17.5 & 12.6 & 15.0 & 41.2 & 13.7 & 13.8 \\
\hline $\begin{array}{l}\text { Column Total } \\
\text { Status in } 1998\end{array}$ & 50.6 & 10.8 & 15.8 & 16.1 & 6.6 & 100 \\
\hline
\end{tabular}


Further comparisons of outcomes among cohorts are reported in Table 5. The first three rows repeat the information on basic retirement levels at the beginning and end of the relevant four year periods. As noted previously, the population share not retired at the end of the four year period is only slightly lower for the Early Boomers exposed to the recession than for those in the older cohorts. Moreover, the decline in the share of the population not retired from the beginning to the end of the four year period of observation is the same for the Early Boomers and the War Babies at 13.8 percent of the cohort. The percent completely retired at the end of the four year period of observation is a couple of points higher for the War Babies compared to the original HRS cohort, and an additional couple of points higher for the Early Boomers compared to the War Babies. But the 11.1 percent increase in the share of the Early Boomers completely retired over the four year period is just slightly less than the 11.7 percent increase in the percent completely retired experienced by the War Baby cohort over the same four year span.

As can be seen in the first row 1 of the bottom panel of Table 5, there is only a small difference in the fraction reducing their work effort (transitioning from not retired to partially or fully retired, or from partially retired to fully retired) between the War Baby and Early Boomer cohorts. The fractions working the same amount or increasing their work effort over the four year period are also similar between the cohorts. This can be seen in rows 2 and 3 in the bottom panel.

Next we consider specific measures of employment change. These include changes in hours of work, long term job tenure, direct reports of layoff or unemployment, the acceptance of a window plan from an employer encouraging retirement, or participation in SSI or the Social Security disability program. In terms of levels of outcomes reported in the top panel of the table, the only substantial difference between cohorts in the level observed in the final year of the four year period is in the fraction unemployed. That fraction increases by 3 percentage points over the four year period for Early Boomers, with a similar (2.9 percentage point) change over the period in the fraction laid off. Layoffs increased by 
1.8 percent and 0.9 percent over the comparable periods for the members of the HRS and War Baby cohorts.

In the bottom panel of Table 5, row 6, there is a substantial difference in the percentage reporting unemployment at any time in the four year period (e.g., 2008 or 2010 for the Early Boomers), from about 3.7 percent for members of the HRS, to 4.5 percent for members of the War Babies, to 7.9 percent for members of the Early Boomers. The difference in the share reporting a layoff over the 4 year period is smaller, at 5.8 percent for the HRS cohort, 7.3 percent for the War Babies, and 7.7 percent for the Early Boomers. As seen in row 4 of the bottom panel of Table 5, there is little change in the share of long tenure workers retiring in the Great Recession compared to earlier years. Indeed, there are fewer retirements among long tenured workers over the period of the Great Recession. Although there is growth over time in the share reporting receipt of SSI or SSDI, there is little difference between the cohorts in the fraction entering these programs over the four year period of observation.

So far we have observed a few adverse labor market outcomes due to the Great Recession against a background of little change in the retirement of long term workers, or in the reductions in work effort observed over the period. At the same time, unemployment is up; there is a one or two percentage point increase in layoffs compared to the experience of the War Babies; and there is an increase in the share of the cohort falling in the not employed, not retired category.

We would like to gain further insight into the relation between the relatively constant share of the workforce still working full time or part time over the period of the Great Recession, and the increase in the share of the cohort who are not retired and not working. 
Table 5: Measures of Levels and Differences in Retirement Status Over Four Year Period: The denominator is total population ages 53 to 58 in the base year. (weighted)

\begin{tabular}{|c|c|c|c|c|c|c|}
\hline & $\begin{array}{l}\text { Original } \\
\text { HRS } \\
1994\end{array}$ & $\begin{array}{l}\text { Original } \\
\text { HRS } \\
1998\end{array}$ & $\begin{array}{l}\text { War- } \\
\text { babies } \\
2000\end{array}$ & $\begin{array}{c}\text { War- } \\
\text { babies } \\
2004\end{array}$ & $\begin{array}{l}\text { Early } \\
\text { Boomers } \\
2006\end{array}$ & $\begin{array}{l}\text { Early } \\
\text { Boomers } \\
2010\end{array}$ \\
\hline \multicolumn{7}{|c|}{ Individual's Retirement Status } \\
\hline Percent not retired & 61.1 & 50.5 & 65.3 & 51.5 & 62.8 & 49.0 \\
\hline Percent partially retired & 8.9 & 11.2 & 9.4 & 11.5 & 10.3 & 11.0 \\
\hline Percent completely retired & 10.2 & 15.8 & 7.8 & 19.5 & 10.7 & 21.8 \\
\hline $\begin{array}{l}\text { Percent working more than } \\
35 \text { hours per week }\end{array}$ & 56.4 & 45.8 & 60.5 & 46.5 & 57.4 & 44.1 \\
\hline $\begin{array}{l}\text { Percent } 10+\text { to } 14+\text { years on } \\
\text { the job }\end{array}$ & 35.6 & 23.8 & 38.8 & 25.0 & 35.7 & 25.4 \\
\hline Percent reporting layoff & 1.9 & 3.7 & 2.5 & 3.4 & 1.9 & 4.8 \\
\hline Percent unemployed & 3.3 & 1.8 & 1.6 & 1.9 & 2.8 & 5.8 \\
\hline Percent taking window plan & 1.4 & 1.8 & 0.6 & 1.0 & 0.4 & 1.3 \\
\hline Percent receiving SSDI/SSI & 2.6 & 4.2 & 6.1 & 8.8 & 7.8 & 8.3 \\
\hline Percent on SSDI & 2.2 & 3.5 & 4.5 & 7.4 & 6.5 & 6.9 \\
\hline Percent on SSI & 0.4 & 0.7 & 1.9 & 1.9 & 1.9 & 2.0 \\
\hline \multicolumn{7}{|c|}{ Change in Individual's Retirement Status } \\
\hline Percent reducing work & \multicolumn{2}{|c|}{11.1} & \multicolumn{2}{|c|}{14.3} & \multicolumn{2}{|c|}{12.8} \\
\hline Percent working same amt. & \multicolumn{2}{|c|}{48.3} & \multicolumn{2}{|c|}{50.5} & \multicolumn{2}{|c|}{47.8} \\
\hline Percent increasing work & \multicolumn{2}{|c|}{2.8} & \multicolumn{2}{|c|}{3.0} & \multicolumn{2}{|c|}{3.6} \\
\hline $\begin{array}{l}\text { Percent of Rs with } 10+\text { years } \\
\text { in the base year who had } 14+ \\
\text { years in the end year }\end{array}$ & \multicolumn{2}{|c|}{66.9} & \multicolumn{2}{|c|}{64.4} & \multicolumn{2}{|c|}{71.2} \\
\hline $\begin{array}{l}\text { Percent reporting layoff any } \\
\text { time in } 4 \text { year period }\end{array}$ & \multicolumn{2}{|c|}{5.8} & \multicolumn{2}{|c|}{7.3} & \multicolumn{2}{|c|}{7.7} \\
\hline $\begin{array}{l}\text { Percent reporting } \\
\text { unemployment any time in } \\
\text { the } 4 \text { year period }\end{array}$ & \multicolumn{2}{|c|}{3.7} & \multicolumn{2}{|c|}{4.5} & \multicolumn{2}{|c|}{7.9} \\
\hline $\begin{array}{l}\text { Percent accepted window } \\
\text { plan any time in } 4 \text { year period }\end{array}$ & \multicolumn{2}{|c|}{3.0} & \multicolumn{2}{|c|}{2.3} & \multicolumn{2}{|c|}{1.9} \\
\hline $\begin{array}{l}\text { Entering SSDI/SSI between } \\
\text { the base year and end year }\end{array}$ & \multicolumn{2}{|c|}{1.6} & \multicolumn{2}{|c|}{2.8} & \multicolumn{2}{|c|}{1.6} \\
\hline
\end{tabular}


Next we would like to consider how the status of those who are not retired but not working is influenced by having experienced a previous layoff. We have just seen in Table 5 that the increase in layoffs due to the recession is modest. Table $5 \mathrm{~A}$, row 4 , shows that a small but increasing share of those who are not retired but not working had previously been laid off. In 1998, 13.2 percent of those not retired and not working had experienced a layoff. This percentage fell to 9.5 percent in 2004 and rose to 17.4 percent in 2010. Among those who are laid off, row 5 shows the fraction who indicate they are not working and not retired has increased from around a quarter to about a half. More specifically, in 1998, 25.6 percent of those laid off indicated they were not retired and not working. In 2004, the percentage had risen to 28.0. However, in 2010, 55 percent of those laid off indicated they were not retired and not working. This is to be expected as those who are laid off and wish to continue working have a more difficult time locating a new job. One additional result in the bottom row of the table reports the share of those not working and not retired who had experienced a layoff sometime over the past four years (two waves). The proportions in 1998, 2004 and 2010 are 22.2 percent, 20.3 percent and 26.7 percent.

One should be careful about drawing conclusions related to the total amount of income or wealth lost due to unemployment. To the extent that those with lower incomes or wealth are more likely to become unemployed, the proportionate decline in income and wealth will be less than the increase in the share of the labor force unemployed. 
Table 5A: Relationship of Layoffs to the Frequency of Reporting Oneself as Not Retired - Not Working

\begin{tabular}{|l|c|c|c||}
\hline & 1998 & 2004 & 2010 \\
\hline $\begin{array}{l}\text { Laid Off and Not Retired- Not Working in } \\
\text { Indicated Year }\end{array}$ & 40 & 23 & 71 \\
\hline $\begin{array}{l}\text { Total Not Retired- Not Working in Indicated } \\
\text { Year }\end{array}$ & 302 & 241 & 129 \\
\hline $\begin{array}{l}\text { Total Layoffs in Indicated Year } \\
\text { Percentage of Those Not Retired- Not } \\
\text { Working Who Experienced a Layoff }\end{array}$ & 156 & 82 & 17.4 \\
\hline $\begin{array}{l}\text { Percentage of Those Laid Off Who Are Also } \\
\text { Not Retired- Not Working }\end{array}$ & 25.6 & 2.5 & 55.0 \\
\hline $\begin{array}{l}\text { Number Experiencing at Least One Layoff } \\
\text { in Last Four Years and Not Retired-Not } \\
\text { Working in Indicated Year }\end{array}$ & 67 & 49 & 109 \\
\hline $\begin{array}{l}\text { Percentage of Those Not Retired- Not } \\
\text { Working Who Experienced at Least One } \\
\text { Layoff in Last Four Years }\end{array}$ & 22.2 & 20.3 & 26.7 \\
\hline
\end{tabular}


As a next step, Tables 5B and 5C disaggregate the results for men and women respectively. For men, the percent not retired is about 7 percentage points lower in 2010 than in 1998 or 2004. But the share not retired in the initial year, 2004, is also lower for men in the Early Boomer cohort. Thus when we look at the percent of men reducing work, as reported in the first row of the bottom panel of Table $5 \mathrm{~B}$, there is only a point or two difference between cohorts in the percentage reducing work effort. Similarly, in the first row of the bottom panel of Table 5C, there is only a small change in the fraction of women reducing their work effort between members of the Early Boomer cohort and those in HRS cohort. Moreover, fewer women in the Early Boomer cohort reduce their work effort compared to those in the War Baby cohort. With regard to the other outcome measures, once again there is no great story that emerges regarding differences between the samples of men and women.

The bottom line here is that reported unemployment is higher for those experiencing the Great Recession, but other measures of activity or related outcomes do not differ much between those affected by the recession and members of older cohorts when they were the same age.

Table 5D examines these outcomes at the household level. A household is included in the sample if either member is 53 to 58 years old in the base year. The variables are similar to those in Table 5, but with one major difference. An outcome is said to occur for the household if it has affected either member of the household. As a result, these outcomes are not mutually exclusive. A household can be classified as being not retired and retired at the same time. Similarly, a household may be counted as having a retirement if either member retired over the four year period, and as increasing work if one of the spouses returned to work.

Again, there are no major differences among cohorts in the changes in retirement status over the course of the four year period. Unemployment is higher over the period of the Great Recession. But other indicators of adverse economic outcomes show little difference. 
Table 5B: Measures of Levels and Differences in Retirement Status Over Four Year Period: Men

\begin{tabular}{|c|c|c|c|c|c|c|}
\hline & $\begin{array}{l}\text { Original } \\
\text { HRS } \\
1994\end{array}$ & $\begin{array}{l}\text { Original } \\
\text { HRS } \\
1998\end{array}$ & $\begin{array}{c}\text { War- } \\
\text { babies } \\
2000\end{array}$ & $\begin{array}{l}\text { War- } \\
\text { babies } \\
2004\end{array}$ & $\begin{array}{l}\text { Early } \\
\text { Boomers } \\
2006\end{array}$ & $\begin{array}{l}\text { Early } \\
\text { Boomers } \\
2010\end{array}$ \\
\hline \multicolumn{7}{|c|}{ Individual's Retirement Status } \\
\hline Percent not retired & 74.9 & 61.1 & 76.8 & 61.1 & 72.0 & 54.3 \\
\hline Percent partially retired & 5.3 & 9.6 & 6.1 & 10.2 & 6.8 & 9.0 \\
\hline Percent completely retired & 9.4 & 16.3 & 7.2 & 19.4 & 10.4 & 21.8 \\
\hline $\begin{array}{l}\text { Percent working more than } \\
35 \text { hours per week }\end{array}$ & 72.4 & 58.6 & 75.4 & 58.3 & 68.8 & 51.6 \\
\hline $\begin{array}{l}\text { Percent } 10+\text { to } 14+\text { years } \\
\text { on the job }\end{array}$ & 44.1 & 29.1 & 47.2 & 31.2 & 42.4 & 28.8 \\
\hline Percent reporting layoff & 2.6 & 4.3 & 2.6 & 3.3 & 1.9 & 5.7 \\
\hline Percent unemployed & 3.5 & 1.8 & 1.5 & 2.6 & 2.8 & 6.5 \\
\hline Percent taking window plan & 2.1 & 2.4 & 0.9 & 1.3 & 0.4 & 1.4 \\
\hline Percent receiving SSDI/SSI & 2.9 & 4.3 & 6.1 & 8.9 & 8.2 & 9.0 \\
\hline Percent on SSDI & 2.7 & 4.0 & 5.2 & 8.4 & 7.3 & 7.6 \\
\hline Percent on SSI & 0.2 & 0.4 & 0.9 & 0.6 & 1.3 & 1.9 \\
\hline \multicolumn{7}{|c|}{ Change in Individual's Retirement Status } \\
\hline Percent reducing work & \multicolumn{2}{|c|}{12.8} & \multicolumn{2}{|c|}{14.9} & \multicolumn{2}{|c|}{13.8} \\
\hline Percent working same amt. & \multicolumn{2}{|c|}{58.0} & \multicolumn{2}{|c|}{58.5} & \multicolumn{2}{|c|}{53.1} \\
\hline Percent increasing work & \multicolumn{2}{|c|}{2.3} & \multicolumn{2}{|c|}{2.8} & \multicolumn{2}{|c|}{2.5} \\
\hline $\begin{array}{l}\text { Percent of Rs with } 10+\text { year } \\
\text { on job in the base year who } \\
\text { had } 14+\text { years in the end year }\end{array}$ & \multicolumn{2}{|c|}{66.0} & \multicolumn{2}{|c|}{66.1} & \multicolumn{2}{|c|}{67.9} \\
\hline $\begin{array}{l}\text { Percent reporting layoff any } \\
\text { time in } 4 \text { year period* }\end{array}$ & \multicolumn{2}{|c|}{6.9} & \multicolumn{2}{|c|}{7.9} & \multicolumn{2}{|c|}{8.9} \\
\hline $\begin{array}{l}\text { Percent reporting } \\
\text { unemployment any time in } 4 \\
\text { year period }\end{array}$ & \multicolumn{2}{|c|}{3.6} & \multicolumn{2}{|c|}{5.3} & \multicolumn{2}{|c|}{8.7} \\
\hline $\begin{array}{l}\text { Percent accepted window } \\
\text { plan any time in } 4 \text { year period }\end{array}$ & \multicolumn{2}{|c|}{4.3} & \multicolumn{2}{|c|}{2.8} & \multicolumn{2}{|c|}{2.3} \\
\hline $\begin{array}{l}\text { Entering SSDI/SSI between } \\
\text { the base year and end year }\end{array}$ & \multicolumn{2}{|c|}{1.4} & \multicolumn{2}{|c|}{2.8} & \multicolumn{2}{|c|}{1.7} \\
\hline
\end{tabular}


Table 5C: Measures of Levels and Differences in Retirement Status Over Four Year Period: Women

\begin{tabular}{|c|c|c|c|c|c|c|}
\hline & $\begin{array}{l}\text { Original } \\
\text { HRS } \\
1994\end{array}$ & $\begin{array}{l}\text { Original } \\
\text { HRS } \\
1998\end{array}$ & $\begin{array}{l}\text { War- } \\
\text { babies } \\
2000\end{array}$ & $\begin{array}{l}\text { War- } \\
\text { babies } \\
2004\end{array}$ & $\begin{array}{l}\text { Early } \\
\text { Boomers } \\
2006\end{array}$ & $\begin{array}{c}\text { Early } \\
\text { Boomers } \\
2010\end{array}$ \\
\hline \multicolumn{7}{|c|}{ I"Individual's Retirement Status } \\
\hline Percent not retired & 48.6 & 41.1 & 55.1 & 43.0 & 54.4 & 44.1 \\
\hline Percent partially retired & 12.2 & 12.7 & 12.4 & 12.6 & 13.5 & 12.7 \\
\hline Percent completely retired & 10.9 & 15.3 & 8.2 & 19.6 & 10.9 & 21.8 \\
\hline $\begin{array}{l}\text { Percent working more than } \\
35 \text { hours per week }\end{array}$ & 41.9 & 34.4 & 47.2 & 36.1 & 47.0 & 37.3 \\
\hline $\begin{array}{l}\text { Percent } 10+\text { to } 14+\text { years } \\
\text { on the job }\end{array}$ & 27.9 & 19.1 & 31.4 & 19.5 & 29.6 & 22.3 \\
\hline Percent reporting layoff & 1.3 & 3.2 & 2.5 & 3.4 & 1.9 & 4.1 \\
\hline Percent unemployed & 3.1 & 1.8 & 1.7 & 1.3 & 2.8 & 5.2 \\
\hline Percent taking window plan & 0.7 & 1.2 & 0.4 & 0.8 & 0.5 & 1.1 \\
\hline Percent receiving SSDI/SSI & 2.3 & 4.1 & 6.1 & 8.8 & 7.5 & 7.7 \\
\hline Percent on SSDI & 1.7 & 3.1 & 3.8 & 6.4 & 5.8 & 6.2 \\
\hline Percent on SSI & 0.6 & 1.0 & 2.9 & 3.0 & 2.6 & 2.2 \\
\hline \multicolumn{7}{|c|}{ Change in Individual's Retirement Status } \\
\hline Percent reducing work & \multicolumn{2}{|c|}{9.5} & \multicolumn{2}{|c|}{13.8} & \multicolumn{2}{|c|}{11.8} \\
\hline Percent working same amt. & \multicolumn{2}{|c|}{39.6} & \multicolumn{2}{|c|}{43.3} & \multicolumn{2}{|c|}{42.9} \\
\hline Percent increasing work & \multicolumn{2}{|c|}{3.3} & \multicolumn{2}{|c|}{3.1} & \multicolumn{2}{|c|}{4.6} \\
\hline $\begin{array}{l}\text { Percent of Rs with } 10+\text { year } \\
\text { on job in the base year who } \\
\text { had } 14+\text { years in the end year }\end{array}$ & \multicolumn{2}{|c|}{68.5} & \multicolumn{2}{|c|}{62.1} & \multicolumn{2}{|c|}{75.3} \\
\hline $\begin{array}{l}\text { Percent reporting layoff any } \\
\text { time in } 4 \text { year period* }\end{array}$ & \multicolumn{2}{|c|}{4.9} & \multicolumn{2}{|c|}{6.7} & \multicolumn{2}{|c|}{6.5} \\
\hline $\begin{array}{l}\text { Percent reporting } \\
\text { unemployment any time in } 4 \\
\text { year period }\end{array}$ & \multicolumn{2}{|c|}{3.8} & \multicolumn{2}{|c|}{3.7} & \multicolumn{2}{|c|}{7.1} \\
\hline $\begin{array}{l}\text { Percent accepted window } \\
\text { plan any time in } 4 \text { year period }\end{array}$ & \multicolumn{2}{|c|}{1.8} & \multicolumn{2}{|c|}{1.4} & \multicolumn{2}{|c|}{1.6} \\
\hline $\begin{array}{l}\text { Entering SSDI/SSI between } \\
\text { the base year and end year }\end{array}$ & \multicolumn{2}{|c|}{1.8} & \multicolumn{2}{|c|}{2.7} & \multicolumn{2}{|c|}{1.5} \\
\hline
\end{tabular}


Table 5D: Measures of Levels and Differences in Retirement Status Over Four Year Period: Households

\begin{tabular}{|c|c|c|c|c|c|c|}
\hline & $\begin{array}{l}\text { Original } \\
\text { HRS } \\
1994\end{array}$ & $\begin{array}{l}\text { Original } \\
\text { HRS } \\
1998\end{array}$ & $\begin{array}{l}\text { War- } \\
\text { babies } \\
2000\end{array}$ & $\begin{array}{c}\text { War- } \\
\text { babies } \\
2004\end{array}$ & $\begin{array}{c}\text { Early } \\
\text { Boomers } \\
2006\end{array}$ & $\begin{array}{l}\text { Early } \\
\text { Boomers } \\
2010\end{array}$ \\
\hline \multicolumn{7}{|c|}{ "Households With at Least One Individual Reporting Indicated Retirement Status } \\
\hline Percent not retired & 59.2 & 48.4 & 63.2 & 46.4 & 59.5 & 44.7 \\
\hline Percent partially retired & 13.7 & 14.6 & 14.3 & 16.3 & 16.1 & 14.7 \\
\hline Percent completely retired & 16.6 & 24.8 & 13.3 & 28.0 & 15.2 & 30.6 \\
\hline $\begin{array}{l}\text { Percent working more than } \\
35 \text { hours per week }\end{array}$ & 70.6 & 58.4 & 74.4 & 59.2 & 70.4 & 56.7 \\
\hline $\begin{array}{l}\text { Percent } 10+\text { to } 14+\text { years } \\
\text { on the job }\end{array}$ & 46.9 & 32.7 & 51.4 & 35.0 & 47.4 & 35.8 \\
\hline Percent Reporting layoff & 3.0 & 5.8 & 4.0 & 5.1 & 3.0 & 7.4 \\
\hline Percent unemployed & 4.5 & 2.5 & 2.4 & 3.0 & 3.8 & 8.3 \\
\hline Percent taking window Plan & 2.3 & 2.7 & 1.1 & 1.3 & 0.6 & 2.0 \\
\hline Percent receiving SSDI/SSI & 3.7 & 5.8 & 9.1 & 12.4 & 10.7 & 11.2 \\
\hline Percent on SSDI & 3.0 & 4.8 & 6.9 & 10.4 & 9.0 & 9.5 \\
\hline Percent on SSI & 0.7 & 1.0 & 2.6 & 2.5 & 2.7 & 2.6 \\
\hline \multicolumn{7}{|c|}{ Households With at Least One Individual Reporting Indicated Change in Retirement Status } \\
\hline Percent reducing work & \multicolumn{2}{|c|}{17.9} & \multicolumn{2}{|c|}{20.8} & \multicolumn{2}{|c|}{19.5} \\
\hline Percent working same amt. & \multicolumn{2}{|c|}{60.9} & \multicolumn{2}{|c|}{63.0} & \multicolumn{2}{|c|}{59.7} \\
\hline Percent increasing work & \multicolumn{2}{|c|}{5.0} & \multicolumn{2}{|c|}{4.7} & \multicolumn{2}{|c|}{5.6} \\
\hline $\begin{array}{l}\text { Percent of Rs with } 10+\text { year } \\
\text { on job in the base year who } \\
\text { had } 14+\text { years in the end year }\end{array}$ & \multicolumn{2}{|c|}{69.7} & \multicolumn{2}{|c|}{68.1} & \multicolumn{2}{|c|}{75.5} \\
\hline $\begin{array}{l}\text { Percent reporting layoff any } \\
\text { time in } 4 \text { year period }\end{array}$ & \multicolumn{2}{|c|}{9.1} & \multicolumn{2}{|c|}{10.9} & \multicolumn{2}{|c|}{11.6} \\
\hline $\begin{array}{l}\text { Percent reporting } \\
\text { unemployment any time in } 4 \\
\text { year period }\end{array}$ & \multicolumn{2}{|c|}{5.2} & \multicolumn{2}{|c|}{6.6} & \multicolumn{2}{|c|}{11.0} \\
\hline $\begin{array}{l}\text { Percent accepted window } \\
\text { plan any time in } 4 \text { Year } \\
\text { period }\end{array}$ & \multicolumn{2}{|c|}{4.6} & \multicolumn{2}{|c|}{3.0} & \multicolumn{2}{|c|}{3.2} \\
\hline $\begin{array}{l}\text { Entering SSDI/SSI between } \\
\text { the base year and end year }\end{array}$ & \multicolumn{2}{|c|}{2.1} & \multicolumn{2}{|c|}{3.8} & \multicolumn{2}{|c|}{2.3} \\
\hline
\end{tabular}

Intact couples with at least one spouse falling in indicated age range in base year are included. Thus this sample includes out of age range spouses that have not been included in earlier tables. 


\section{Adverse Events Affecting Employment}

Table 6 documents the incidence of adverse events on the job. Row 1 reports the numbers and related percentages of respondents who indicated there was a change in their employment situation that encouraged them to leave the job. The details as to exactly what changed are reported in subsequent rows. Other columns report for each cohort the relative importance of the event among the employed and for the total in the cohort. The bottom row of the first panel reports whether there had been a permanent reduction in employment at the firm.

These data confirm our earlier findings. Although adverse events of this type have received a great deal of publicity, the incidence of these events during the Great Recession is no different from their incidence in previous years. Roughly 10 percent of employed respondents report leaving their job because of these adverse events in all three periods analyzed. We do see evidence of the weakening labor market in the recession. Specifically, a larger share of respondents from the Early Boomer cohort reported their employer had experienced a decline in employment, or that they would have experienced a layoff. 
Table 6: Adverse Events Affecting the Employment of Early Boomers, War Babies, and HRS Cohorts: Age Eligible (weighted)

\begin{tabular}{|c|c|c|c|c|c|c|c|c|c|}
\hline & \multicolumn{3}{|c|}{$2008 / 2010$} & \multicolumn{3}{|c|}{$2002 / 2004$} & \multicolumn{3}{|c|}{ 1996/1998 } \\
\hline & Number & $\begin{array}{c}\text { \% of Rs } \\
\text { with } \\
\text { employment }\end{array}$ & $\begin{array}{l}\% \text { of } \\
\text { Total }\end{array}$ & Number & $\begin{array}{c}\text { \% of Rs } \\
\text { with } \\
\text { employment }\end{array}$ & $\begin{array}{l}\% \text { of } \\
\text { Total }\end{array}$ & Number & $\begin{array}{c}\text { \% of Rs } \\
\text { with } \\
\text { employment }\end{array}$ & $\begin{array}{l}\% \text { of } \\
\text { Total }\end{array}$ \\
\hline Employment situation change led to exit & 165 & 10.4 & 6.8 & 180 & 10.6 & 7.1 & 248 & 9.5 & 6.0 \\
\hline Supervisor, coworker encouraged exit & 9 & 0.6 & 0.4 & 9 & 0.5 & 0.3 & 16 & 0.6 & 0.4 \\
\hline Wages/hours reduced or about to be & 26 & 1.4 & 0.9 & 10 & 0.6 & 0.4 & 27 & 1.0 & 0.6 \\
\hline Would have been laid off & 11 & 0.8 & 0.5 & 10 & 0.7 & 0.5 & 13 & 0.5 & 0.3 \\
\hline New job duties/location & 18 & 1.3 & 0.9 & 20 & 1.1 & 0.8 & 45 & 1.8 & 1.1 \\
\hline Became eligible for pension & 2 & 0.2 & 0.1 & 5 & 0.4 & 0.2 & 18 & 0.7 & 0.4 \\
\hline Employer changed health insurance & 2 & 0.2 & 0.1 & 5 & 0.3 & 0.2 & 0 & 0 & 0 \\
\hline Special early retirement incentive offer & 7 & 0.4 & 0.3 & 15 & 0.9 & 0.6 & 29 & 1.3 & 0.8 \\
\hline Other reasons & 110 & 6.8 & 4.5 & 69 & 4.0 & 2.7 & 113 & 4.4 & 2.8 \\
\hline $\begin{array}{l}\text { Did your employer experience a permanent } \\
\text { reduction in employment? }\end{array}$ & 250 & 14.4 & 9.4 & 216 & 12.9 & 8.7 & 294 & 11.5 & 7.3 \\
\hline Number of employees & 1641 & 1641 & 2547 & 1719 & 1719 & 2627 & 2625 & 2625 & 4215 \\
\hline Unemployed and looking for work & 211 & & 8.0 & 106 & & 4.4 & 161 & & 3.8 \\
\hline Laid off or would have been laid off & 206 & & 8.1 & 179 & & 7.2 & 252 & & 6.0 \\
\hline Number of observations in the sample & 2547 & & 2547 & 2627 & & 2627 & 4215 & & 4215 \\
\hline
\end{tabular}

1- $\mathrm{R}$ is asked whether his/her employment situation changed in some way that encouraged $\mathrm{R}$ to leave. Follow-up asks how it changed. $\mathrm{R}$ reported change in employment situation either in end year or intermediate year in the period, e.g., for early boomers in 2010 or 2008.

2- Lay off: includes layoffs, temporary or seasonal job that ended; contract over; lack of work/clients/customers; downsizing. 


\section{Adverse Events Affecting Pensions}

Table 7 reports adverse events affecting the pensions held by members of these three cohorts. ${ }^{16}$

The percentage reporting they lost their pension is about twice as high during the Great Recession as over comparable periods experienced by older cohorts, 6.1 percent vs. 3.3 percent and 2.9 percent in earlier years. Many fewer report their pensions changed during the Great Recession. One reason why is that the questions are different in 2008 and 2010 from earlier survey years.

A substantially higher proportion of those still with a DB plan in 2006 reported their DB coverage changed by 2008 or 2010, while fewer changes in coverage were reported by members of the Early Boomer cohort who had DC plans compared to those from older cohorts. The bottom line is reported in Table 2B. Average pension wealth increased by about 8 percent for members of the original HRS cohort, with the entire increase coming from wealth held in DC plans. In contrast, total pension wealth remained steady for members of the Early Boomer cohort over the period of the Great Recession, with DB values declining and DC values growing. Remember again that rollovers of pensions will move funds from the pension category to the IRA category. In both periods the growth in IRA balances was substantial, growing by roughly half over a four year period.

${ }^{16}$ Variable definitions in Table 7 are as follows. Definitions are presented for Early Boomers. Analogous definitions apply to other cohorts:

1- The dashes signify that the required information is not available.

2- Lost pension: Rs reported having pension coverage in 2006/2008, but working at the same employment with no coverage in 2008 or 2010, respectively.

3- Pension rules changed: R reported pension rules changed for his/her plan either in 2008 or 2010. In survey years prior to 2008, respondents were asked a general question about any rule changes; if the rules governing your pension have changed since last interview. But in 2008 and 2010 they are asked this question about each specific plan separately.

4- $\mathrm{DB} /$ comb coverage: if $\mathrm{R}$ reported working at the same employment and had at least one $\mathrm{DB}$ or combination plan in 2008 or 2010.

5- DB Pension Coverage Changed: if $\mathrm{R}$ reported at least one DB/combination plan in 2006 and while working at the same employment had no DB/combination plan in 2008 or 2010.

6- $\quad \mathrm{DC} /$ comb coverage: if $\mathrm{R}$ reported working at the same employment and had at least one DC or combination plan in 2008 or 2010.

7- DC Pension Coverage Changed: if R reported at least one DC/combination plan in 2006 and while working at the same employment had no DC/combination plan either in 2008 or 2010.

8- DB Pension Rules Changed: If R reported at least one DB/combination plan in either 2008 or 2010 and reported a change in its rules. This question was not asked in surveys before 2008.

9- DC Pension Rules Changed: If R reported at least one DC/combination plan in either 2008 or 2010 and reported a change in its rules. This question was not asked in surveys before 2008.

10- Reduced stocks: R reported his most important DC allocations changed to less stock either in 2008 or 2010. This question was not asked in surveys before 2004. 
Table 7: Adverse Events Affecting the Pensions of Early Boomers, War Babies, and HRS Cohorts: Age Eligible (weighted)

\begin{tabular}{|c|c|c|c|c|c|c|c|c|c|}
\hline & \multicolumn{3}{|c|}{$2008 / 2010$} & \multicolumn{3}{|c|}{$2002 / 2004$} & \multicolumn{3}{|c|}{$1996 / 1998$} \\
\hline & Number & $\begin{array}{c}\text { \% of Rs } \\
\text { with } \\
\text { pension }\end{array}$ & $\begin{array}{l}\% \text { of } \\
\text { Total }\end{array}$ & Number & $\begin{array}{c}\text { \% of Rs } \\
\text { with } \\
\text { pension }\end{array}$ & $\begin{array}{l}\% \text { of } \\
\text { Total }\end{array}$ & Number & $\begin{array}{c}\text { \% of Rs } \\
\text { with } \\
\text { pension }\end{array}$ & $\begin{array}{l}\% \text { of } \\
\text { Total }\end{array}$ \\
\hline Lost pension in $2008 / 2010$ & 82 & 6.1 & 3.2 & 46 & 3.3 & 1.8 & 60 & 2.9 & 1.4 \\
\hline Pension rules changed & 54 & 4.4 & 2.3 & 170 & 14.2 & 7.7 & 240 & 11.9 & 5.7 \\
\hline Plan terminated & 0 & 0 & 0 & - & - & - & - & - & - \\
\hline Frozen benefits & 6 & 0.7 & 0.4 & - & - & - & - & - & - \\
\hline Stopped contributing & 4 & 0.4 & 0.2 & - & - & - & - & - & - \\
\hline Contribution level changed & 4 & 0.3 & 0.2 & - & - & - & - & - & - \\
\hline Required age/service changed & 7 & 0.4 & 0.2 & - & - & - & - & - & - \\
\hline Benefits formula changed & 2 & 0.2 & 0.1 & - & - & - & - & - & - \\
\hline Other/DK/RF & 31 & 2.0 & 1.0 & - & - & - & - & - & - \\
\hline DB/comb coverage in 2008 or 2010 & 551 & 52.8 & 24.5 & 659 & 64.2 & 29.4 & 1110 & 68.1 & 29.1 \\
\hline DB Pension Coverage Changed & 23 & 25.3 & 1.0 & 83 & 14.1 & 3.0 & 139 & 14.3 & 3.3 \\
\hline DB Pension Rules Changed & 11 & 13.4 & 1.2 & - & - & - & - & - & - \\
\hline DC/comb coverage in 2008 or 2010 & 804 & 77.3 & 37.5 & 730 & 71.1 & 35.4 & 998 & 62.3 & 29.0 \\
\hline DC Pension Coverage Changed & 31 & 14.1 & 1.1 & 100 & 16.2 & 4.0 & 151 & 20.6 & 3.8 \\
\hline DC Pension Rules Changed & 14 & 7.7 & 1.3 & - & - & - & - & - & - \\
\hline Reduced stocks & 42 & 23.2 & 9.9 & - & - & - & - & - & - \\
\hline $\begin{array}{l}\text { Number of Observations with a } \\
\text { pension in } 2006 / 2008\end{array}$ & 1279 & 1279 & 2547 & 1341 & 1341 & 2627 & 1947 & 1947 & 4215 \\
\hline
\end{tabular}




\section{Adverse Events Affecting Housing}

Table 8 reports the experience of the Early Boomer cohort with adverse events affecting their housing. Twenty-eight percent of those with housing and 29 percent of the sample reported there is a poor housing market in their area. But only 3.2 percent of homeowners fell behind in their mortgage, with 0.9 percent having reported they faced possible foreclosure. Most had paid off enough of their mortgage that they were not going to be under water as a result of the recession. Moreover, while multiple adverse events are a major issue for younger members in the population, only 0.3 percent of this older sample reported having lost a job and facing foreclosure or possible foreclosure. 
Table 8: Housing Problems Experienced By Early Boomers and Reported in 2010: weighted

\begin{tabular}{|c|c|c|c|c|}
\hline \multirow[t]{2}{*}{ Adverse Events } & \multicolumn{2}{|c|}{ Number } & \multirow{2}{*}{$\begin{array}{l}\% \text { of Rs with } \\
\text { Housing } \\
\text { Experiencing } \\
\text { Adverse } \\
\text { Outcome }\end{array}$} & \multirow{2}{*}{$\begin{array}{c}\% \text { of Total } \\
\text { Sample } \\
\text { Experiencing } \\
\text { Adverse } \\
\text { Outcome }\end{array}$} \\
\hline & $\begin{array}{l}\text { Of Those } \\
\text { with } \\
\text { Housing }\end{array}$ & $\begin{array}{l}\text { Of } \\
\text { Total }\end{array}$ & & \\
\hline Poor housing market in R's area & 586 & 760 & 28.3 & 29.1 \\
\hline $\begin{array}{l}\text { Fallen more than } 2 \text { months behind mortgage } \\
\text { payment }\end{array}$ & 71 & 78 & 3.2 & 2.6 \\
\hline Gone through foreclosure past 2 years & 0 & 20 & 0 & 0.7 \\
\hline House Foreclosed & 0 & 10 & 0 & 0.3 \\
\hline Facing possible foreclosure & 21 & 21 & 0.9 & 0.7 \\
\hline Number of observations in 2008 & 2021 & 2547 & 2021 & 2547 \\
\hline $\begin{array}{l}\text { Multiple Bad Events - Job Loss Plus } \\
\text { foreclosure or possible foreclosure }\end{array}$ & 10 & 10 & 0.4 & 0.3 \\
\hline Number of observations & 1487 & 2547 & 1487 & 2547 \\
\hline
\end{tabular}

1- Poor housing market in R's area: R rated housing market in his/her area as poor either in 2008 or 2010.

2- Multiple Bad Events: R reported unemployed and looking for work in 2008 or 2010 or reported being laid off or left job fearing being laid off in 2008 or 2009 and reported his/her house being foreclosed or facing possible foreclosure in 2010. 


\section{Conclusions:}

The retirement wealth held by those ages 53 to 58 at the onset of the Great Recession in 2006 declined by a relatively modest 2.8 percentage points by 2010. In more normal times, their wealth would have increased over these four years. Members of older cohorts accumulated an additional 5 percent of wealth over the same age span. To be sure, a part of that accumulation was the result of the upside of the housing bubble.

The adverse labor market effects of the Great Recession are more modest. Although there is an increase in unemployment, that increase is not mirrored in a decline in full-time work or partial retirement. All told, the retirement behavior of the Early Boomer cohort looks similar, at least so far, to the behavior observed for members of older cohorts at comparable ages.

Very few in the population nearing retirement age have experienced multiple adverse events. Although most of the loss in wealth is due to a fall in the net value of housing, because very few in this cohort have found their housing wealth under water, and housing is the one asset this cohort is not likely to cash in for another decade or two, there is time for their losses in housing wealth to recover. The wealth holdings of poorer households were least affected by the recession. Relative losses are greatest for those who initially had the highest wealth when the recession began.

Among our more specific findings:

1. Social Security and pensions, accounting for 55 percent of the total wealth of those approaching retirement at the onset of the recession, retained their value and thus played a major role in cushioning the effects of the recession on total wealth.

2. Those in the bottom quartile of wealth holding households experienced only a 1 percent fall in real wealth. Social Security accounts for 79 percent of their total wealth. 
3. Although 51 percent of households in the Early Boomer cohort experienced a decline in real wealth, 48 percent experienced an increase. Losers outnumbered gainers in all but two asset categories, DC pension wealth and IRA pension wealth.

4. Ordering households by real wealth, 39 percent of the members of the lowest wealth decile experienced a loss in wealth. In contrast, 70 percent of the households in the highest wealth decile experienced a loss in wealth. The share of households experiencing at least a 20 percent decline in real wealth ranges from 12 percent of households falling in the lowest wealth decile up to 48 percent of households in the highest wealth decile.

5. The share of households experiencing a gain in wealth includes 49 percent of the households in the lowest wealth decile in 2006, falling to 30 percent of the households in the highest wealth decile. Thirty percent of the households in the lowest wealth decile experienced a wealth gain of at least 20 percent, while 9 percent of the households in the highest wealth decile experienced a gain of at least 20 percent.

6. The share of the population not retired, as measured by a combination of hours of work and self reported status, fell from 62.8 percent of the members of the Early Boomer cohort in 2006 to 49.2 percent in 2010. For men, the share of the population not retired declined by 17.4 percent over the four year period from a base of 72.0 percent, while for women the decline was 10.1 percent from a base of 54.4 percent.

7. The 13.8 percent decline in the share of the population classified as not retired in the Early Boomer cohort is identical to the decline observed for members of the War Baby cohort, six years older, and greater than the 10.6 percent decline observed for members of the original HRS cohort twelve years earlier. 
8. The increases in the fractions unemployed and those reporting they are not employed but not retired, was substantially greater during the period of the Great Recession than in comparable periods experienced by members of older cohorts.

9. Thus a key question remains. While unemployment was higher during the recession than in earlier years, employment was not reduced and retirements were not accelerated. One reason is that some who could retain their jobs postponed their retirement. Second, those who were laid off were less likely to leave the labor force. On net, the increase in the number who remained at work was enough to offset the job losses of those who had been laid off. 


\section{References}

Bricker, Jesse, Brian K. Bucks, Arthur Kennickell, Traci L. Mach and Kevin Moore. 2011. "Drowning or Weathering the Storm? Changes in Family Finances from 2007 to 2009." NBER Working Paper 16985.

Bosworth, Barry P. and Gary Burtless. 2010. "Recessions, Wealth Destruction and the Timing of Retirement. Center for Retirement Research at Boston College. Working Paper 201022.

Butrica, Barbara A., Richard W. Johnson and Karen E. Smith. 2011. "The Potential Impact of the Great Recesson on Future Retirement Incomes". Center for Retirement Research at Boston College. Working Paper 2011-9.

Chakrabarti, Rajashri, Donghoon Lee, Wilber van der Klaauw and Basit Zafar. 2011. "Household Debt and Saving During the 2007 Recession". NBER Working Paper 16999.

Chan, Sewin and Ann H. Stevens. 2004 "How Does Job Loss Affect the Timing of Retirement?” Contributions to Economic Analysis and Policy 3(1), article 5. http://www.bepress.com/bejeap/contributions/

Coile, Courtney and Phillip B. Levine. 2009. "The Market Crash and Mass Layoffs: How the Current Economic Crisis May Affect Retirement”. NBER Working Paper 15395.

Copeland, Craig. 2011. "Labor-Force Participation Rates of the Population Age 55 and Older: What Did the Recession Do to the Trends?" Employee Benefit Research Institute Notes 32(3).

Farber, Henry S. 2011. "Job Loss in the Great Recession: Historical Perspective from the Displaced Workers Survey", 1984-2010.

Goda, Gopi Shah, John B. Shoven and Sita Nataraj Slavov. 2011. American Economic Review Papers and Proceedings 101(3): 29-34. . 2011. "Recessions, Retirement and Social Security". American Economic

Review Papers and Proceedings 101(3): 23-28.

Gustman, Alan L. and Thomas L. Steinmeier. 2002. "Retirement and the Stock Market Bubble". National Bureau of Economic Research. Working Paper 9404. . 2009a. "How Changes in Social Security Affect Recent Retirement Trends".

Research on Aging 31(2): 261-290. . 2009b. "Integrating Retirement Models". NBER Working Paper 15607.

Gustman, Alan L., Thomas L. Steinmeier and Nahid Tabatabai. 2010a. Pensions in the Health and Retirement Study. Harvard University Press. . 2010b. "What the Stock Market Decline Means for the Financial Security and Retirement Choices of the Near-Retirement Population”. Journal of Economic Perspectives (Winter).

Helman, Ruth, Craig Copeland and Jack VanDerhei. 2011. "The 2011 Retirement Confidence Survey: Confidence Drops to Record Lows, Reflecting "the New Normal". Issue Brief No. 355.

Helppie McFall, Brooke. 2011. "Crash and Wait? The Impact of the Great Recession on the Retirement Plans of Older Americans". American Economic Review Papers and Proceedings 101(3): 40-44.

Hurd, Michael D., Monika Reti and Susann Rohwedder. 2009. "The Effect of Large Capital Gains or Losses on Retirement" In Developments in the Economics of Aging. David A. Wise, editor. Chicago, University of Chicago Press: 127-163. 
Hurd, Michael D. and Susann Rohwedder. 2010. "Effects of the Financial Crisis and Great Recession on American Households". NBER Working Paper 16407.

Johnson, Richard W. and Corina Mommaerts. 2011. "Age Differences in Job Displacement, Job Search and Reemployment". Center for Retirement Research at Boston College. Working Paper Number 2011-3.

Johnson, Richard W. and Janice S. Park. 2011. "Can Unemployed Older Workers Find Work?" Urban Institute Brief Number 25, January.

Munnell, Alicia H., Dan Muldoon and Steven A. Sass. 2009. "Recessions and Older Workers". Center for Retirement Research at Boston College. Working Paper Number 9-2.

National Research Council. 2010. "Assessing the Impact of Severe Economic Recession on the Elderly: Summary of a Workshop.

Rix, Sara E. 2011. "Recovering from the Great Recession: Long Struggle Ahead for Older Americans". AARP Policy Institute.

Rohwedder, Susann. 2009. “American Life Survey: Evidence on How the Financial Crisis Has Affected American Households”. Paper presented at Michigan Retirement Research Center Research Workshop, April 3 and 4, 2009. No URL available.

Sass, Steven A., Courtney Monk and Kelly Haverstick. 2010. "Workers' Response to the Market Crash: Save More, Work More?" Center for Retirement Research at Boston College. Working Paper 10-3, February, 2010.

Stevens, Ann Huff. 2008. "Retirement Wealth Across Cohrots: The Role of Earnings Inequality and Pension Changes". University of Michigan Retirement Research Center, Working Paper 2008-186.

Stevens, Ann Huff and Sewin Chan. 2001. "Job Loss and Employment Patterns of Older Workers." Journal of Labor Economics 19(2): 484-521.

The Conference Board. 2011. "U.S. Workers Delaying Retirement: What Businesses Can Learn from the Trends of Who, Where and Why". By Gad Levanon, Ben Cheng and Jeremy Goldman. May.

Venti, Steven F. and David A. Wise. 2004. "Aging and Housing Equity: Another Look". In Perspectives on the Economics of Aging, ed. David A. Wise. Chicago: University of Chicago Press for NBER: 127-175.

Wolff, Edward N. 2011. "Pensions in the 2000s: the Lost Decade?" NBER Working Paper No. 16991. 


\section{Appendix 1: Procedures used in empirical calculations of Table 1}

Observations with total wealth falling in the top and bottom one percent are excluded.

The sample includes all age eligible households in 2006 and 2010. Age eligible respondents include respondents with one member in their household who is 53 to 58 in 2006. Households that experienced a divorce, separation, entry of new spouses or partners during that period are excluded from the sample.

Social Security wealth is calculated as of claiming age in 2004. Data from version 2 of the HRS calculations, directed by Kandice Kapinos, are used. These data include own, spouse and survivor benefits where the household is entitled to them. Calculations assume the respondent claims benefits as soon as eligible and that earnings end during the 2004 period. This means that many people are a number of years away from being able to claim their Social Security benefits at age 62. We use the "claim now" scenario to put the Social Security benefits on the same footing as the defined benefit and defined contribution pensions, which are evaluated as of the last date the person is observed to work. This is only a rough approximation for the Social Security data because we do not have adequate data to update the claim now values for Social Security between 2004 and 2010 associated with additional work. The mean of the ratio of the benefits if claim now to the benefits at normal retirement age is 0.87 ; the ratio varies between zero and 1.6, with one extreme value equal to 2.6. For those who are already receiving benefits in the base year, the actual benefit amount is included.

More specifically, the present value of Social Security wealth in 2006 is calculated as the present value of Social Security wealth in 2004 from the HRS calculations by Kapinos increased to the base year of 2010. The 2004 figure for Social Security wealth is multiplied by 1.058 to the 6th power, then multiplied by 1/1.028 to the fourth power. As noted in footnote 9 , in all calculations we use a CPI increase of 2.8 percent per year and a nominal interest rate of 5.8 percent, approximations taken from the 
Report of the Board of Trustees of the Social Security Administration. The present value of Social Security wealth in 2010 and the present value of Social Security wealth in 2006 expressed in 2010 dollars multiplies the present value of wealth in 2004 by 1.058 to the 6th power.

DB benefits are the sum of expected benefits and any remaining benefits if the respondent reported already receiving benefits. Expected benefits from current jobs are prorated values for the most important DB plan and are based on self-reported data. DB benefits from previous jobs are in current dollars as of 2006 and 2010. If DB plans, from current or previous jobs, are in pay status the present value of the remaining benefits as of 2006 and 2010 are calculated. DC balances are the sum of all DC accounts from respondents' current job and/or previous jobs. Although, financial asset variables are imputed and available in the Rand HRS data set for 2006, they are not available for 2010. Therefore, we do not use the Rand data in this calculation and instead impute missing values using a nearest neighbor approach. When comparing data across earlier years we do use the Rand data and take their imputations for both periods being compared.

We impute for missing, don't know, or refused responses. We use a variety of methods to impute depending on the number of observations available. These include a mixed method, a regression which forms the basis for a nearest neighbor imputation, or when few observations are available, a hot-decking process. Imputations are also used when values are reported only in the form of brackets. The imputation sample includes only those who meet the required conditions. For example, DB values are imputed only from that set of observations reporting they have a DB plan. The explanatory covariates for pension variables include employment status, age, education, race, earnings, marital status, occupation, industry, union membership, if government employee, and job tenure. For financial assets, we used gender, marital status, and if there were one or two earners in the household. 
Results are weighted. We have used household weights from the 2006 survey. 
Appendix Table 1A: Components of Wealth in 2006 and 2010 For the Median 10\% of Wealth Holding Households with at Least One Member Born from 1948 to 1953. Weighted.

\begin{tabular}{||c|c|c|c|c|c|c|c||}
\hline \multirow{2}{*}{ Source of Wealth } & \multicolumn{2}{|c|}{2006} & \multicolumn{2}{|c|}{2010 Current \$ } & \multicolumn{2}{c||}{2006 in \$2010 } \\
\cline { 2 - 9 } & $\begin{array}{c}\text { Value } \\
(\$)\end{array}$ & $\begin{array}{c}\text { Percent of } \\
\text { Total } \\
(\%)\end{array}$ & $\begin{array}{c}\text { Value } \\
(\$)\end{array}$ & $\begin{array}{c}\text { Percent of } \\
\text { Total } \\
(\%)\end{array}$ & $\begin{array}{c}\text { Ratio } \\
2010 / \\
2006\end{array}$ & $\begin{array}{c}\text { Value } \\
(\$)\end{array}$ & $\begin{array}{c}\text { Ratio } \\
2010 / \\
2006\end{array}$ \\
\hline \hline Total & $\$ 581 \mathrm{k}$ & 100 & $\$ 621 \mathrm{k}$ & 100 & 1.09 & $\$ 649 \mathrm{k}$ & 0.96 \\
\hline Social Security Plus Pensions & 372 & 64.0 & 420 & 67.6 & 1.17 & 415 & 1.01 \\
\hline Social Security & 255 & 43.9 & 284 & 45.7 & 1.13 & 285 & 1.00 \\
\hline Pension Value & 117 & 20.1 & 136 & 21.9 & 1.27 & 130 & 1.05 \\
\hline DB Value & 84 & 14.5 & 90 & 14.5 & 1.18 & 94 & 0.96 \\
\hline DC Value & 33 & 5.7 & 46 & 7.4 & 1.53 & 37 & 1.24 \\
\hline Current DC Balances & 26 & 4.5 & 31 & 5.0 & 1.35 & 29 & 1.07 \\
\hline Current DC in Stocks & 18 & 3.1 & 18 & 2.9 & 1.20 & 20 & 0.90 \\
\hline Net House Value & 122 & 21.0 & 88 & 14.2 & 0.70 & 137 & 0.64 \\
\hline Real Estate & 16 & 2.8 & 9 & 1.4 & 0.56 & 18 & 0.50 \\
\hline Business Assets & 8 & 1.4 & 21 & 3.4 & 2.63 & 9 & 2.33 \\
\hline Net Value of Vehicles & 16 & 2.8 & 15 & 2.4 & 0.88 & 18 & 0.83 \\
\hline Financial Assets & 20 & 3.4 & 16 & 2.6 & 0.76 & 23 & 0.70 \\
\hline Direct Stocks Holdings & 7 & 1.2 & 10 & 1.6 & 1.43 & 7 & 1.43 \\
\hline IRA Assets & 26 & 4.5 & 52 & 8.4 & 1.93 & 29 & 1.79 \\
\hline IRA in Stocks Value & 19 & 3.3 & 33 & 5.3 & 1.65 & 21 & 1.57 \\
\hline $\begin{array}{l}\text { IRA Plus Stocks Holdings Plus } \\
\text { DC in Stocks }\end{array}$ & 49 & 8.4 & 68 & 11.0 & 1.48 & 54 & 1.26 \\
\hline Observations & & & & & & & 200 \\
\hline \hline
\end{tabular}


Appendix Table 1B: Components of Wealth in 2006 and 2010 For Households Falling in the Lowest Quartile When Ranked According to Wealth. Weighted.

\begin{tabular}{|c|c|c|c|c|c|c|c|}
\hline \multirow{2}{*}{ Source of Wealth } & \multicolumn{2}{|c|}{2006} & \multicolumn{3}{|c|}{2010 Current \$ } & \multicolumn{2}{|c|}{2006 in $\$ 2010$} \\
\hline & $\begin{array}{l}\text { Value } \\
(\$)\end{array}$ & $\begin{array}{c}\text { Percent of } \\
\text { Total } \\
(\%)\end{array}$ & $\begin{array}{c}\text { Value } \\
(\$)\end{array}$ & $\begin{array}{c}\text { Percent of } \\
\text { Total } \\
(\%)\end{array}$ & $\begin{array}{l}\text { Ratio } \\
2010 / \\
2006 \\
\end{array}$ & $\begin{array}{l}\text { Value } \\
(\$)\end{array}$ & $\begin{array}{l}\text { Ratio } \\
2010 / \\
2006 \\
\end{array}$ \\
\hline Total & $\$ 111.1 \mathrm{k}$ & 100 & $\$$ \$123k & 100 & 1.11 & $\$ \$ 124 k$ & 0.99 \\
\hline Social Security Plus Pensions & 93.0 & 83.7 & 104.2 & 84.7 & 1.12 & 103.9 & 1.00 \\
\hline Social Security & 88 & 79.2 & 97.2 & 79.0 & 1.10 & 98.3 & 0.99 \\
\hline Pension Value & 5 & 4.5 & 7 & 5.7 & 1.40 & 5.6 & 1.25 \\
\hline DB Value & 2.6 & 2.3 & 3.7 & 3.0 & 1.42 & 2.9 & 1.28 \\
\hline DC Value & 2.4 & 2.2 & 3.2 & 2.6 & 1.33 & 2.7 & 1.19 \\
\hline Current DC Balances & 2 & 1.8 & 2.5 & 2.0 & 1.25 & 2.3 & 1.09 \\
\hline Current DC in Stocks & 1.3 & 1.2 & 11.1 & 0.9 & 0.85 & 1.4 & 0.79 \\
\hline Net House Value & 11.7 & 10.5 & 14.1 & 11.5 & 1.21 & 13 & 1.08 \\
\hline Real Estate & 0.9 & 0.8 & 0.9 & 0.7 & 1.0 & 1 & 0.90 \\
\hline Business Assets & 1 & 0.9 & 0.6 & 0.5 & 0.60 & 1.1 & 0.55 \\
\hline Net Value of Vehicles & 4.5 & 4.1 & 4.6 & 3.7 & 1.02 & 5 & 0.92 \\
\hline Financial Assets & -1.7 & -1.5 & -3.5 & -2.8 & 2.06 & -2 & 1.75 \\
\hline Direct Stocks Holdings & 0.2 & 0.2 & 0.4 & 0.3 & 2.00 & 0.2 & 2.00 \\
\hline IRA Assets & 1.7 & 1.5 & 2.1 & 1.7 & 1.24 & 2 & 1.05 \\
\hline IRA in Stocks Value & 0.8 & 0.7 & 1.2 & 1.0 & 1.50 & 0.9 & 1.33 \\
\hline $\begin{array}{l}\text { IRA Plus Stocks Holdings Plus DC } \\
\text { in Stocks }\end{array}$ & 2.5 & 2.3 & 3.0 & 2.4 & 1.20 & 2.8 & 1.07 \\
\hline Observations & \multicolumn{2}{|c|}{478} & \multicolumn{3}{|c|}{478} & \multicolumn{2}{|c|}{478} \\
\hline
\end{tabular}

In calculating bottom quartile, wealth rankings are unweighted although the data in the table are weighted. 
Appendix Table 1C: Households with Negative Net House Value, Gross House Values, and Mortgages in 2006 and 2010. (weighted)

\begin{tabular}{|c|c|c|c|c|}
\hline & \multicolumn{2}{|c|}{$\begin{array}{c}\text { Households with Negative } \\
\text { Net House Value }\end{array}$} & \multicolumn{2}{|c|}{ All Households } \\
\hline & $\begin{array}{l}\text { Number of } \\
\text { Households }\end{array}$ & $\begin{array}{c}\text { Net Value } \\
\$\end{array}$ & $\begin{array}{c}\text { Gross House } \\
\text { Value } \\
\$ \\
\end{array}$ & $\underset{\$}{\text { Mortgage Value }}$ \\
\hline 2006 & 42/1949 & $-81,716$ & 218,409 & 68,862 \\
\hline 2010 & 92/1949 & $-66,047$ & 194,203 & 66,319 \\
\hline \multicolumn{5}{|c|}{ Median 10\% } \\
\hline 2006 & $3 / 200$ & $-28,002$ & 198,189 & 75,791 \\
\hline 2010 & 17/193 & $-90,817$ & 174,149 & 86,233 \\
\hline \multicolumn{5}{|c|}{ Bottom Quartile } \\
\hline 2006 & $11 / 478$ & $-77,188$ & 28,605 & 16,945 \\
\hline 2010 & $22 / 478$ & $-55,583$ & 33,801 & 19,683 \\
\hline
\end{tabular}


Table 2A: The Value of Components of Wealth For Members of Various HRS Cohorts Over the Period from the Second to Fourth Wave They Are in the Survey in Current Dollars: weighted

\begin{tabular}{|c|c|c|c|c|c|c|}
\hline \multirow[b]{2}{*}{ Source of Wealth } & \multicolumn{6}{|c|}{ Current Dollars } \\
\hline & $\begin{array}{c}\text { Original } \\
\text { HRS } \\
1994\end{array}$ & $\begin{array}{c}\text { Original } \\
\text { HRS } \\
1998\end{array}$ & $\begin{array}{c}\text { War- } \\
\text { babies } \\
2000\end{array}$ & $\begin{array}{c}\text { War- } \\
\text { babies } \\
2004\end{array}$ & $\begin{array}{c}\text { Early } \\
\text { Boomers } \\
2006\end{array}$ & $\begin{array}{c}\text { Early } \\
\text { Boomers } \\
2010\end{array}$ \\
\hline Total & $\$ 507 \mathrm{k}$ & $\$ 609 k$ & $\$ 657 \mathrm{k}$ & $\$ 758 \mathrm{k}$ & $\$ 780 \mathrm{k}$ & $\$ 847 \mathrm{k}$ \\
\hline Social Security Plus Pensions & 291 & 333 & 364 & 387 & 426 & 473 \\
\hline Social Security & 162 & 180 & 181 & 202 & 229 & 256 \\
\hline Pension Value & 130 & 153 & 182 & 185 & 197 & 218 \\
\hline DB Value & 106 & 119 & 128 & 130 & 135 & 141 \\
\hline DC Value & 24 & 34 & 54 & 55 & 62 & 77 \\
\hline Current DC Balances & 19 & 25 & 46 & 40 & 47 & 51 \\
\hline Current DC in Stocks & - & - & - & - & 29 & 25 \\
\hline Net House Value & 69 & 82 & 85 & 131 & 150 & 128 \\
\hline Real Estate & 32 & 34 & 32 & 44 & 32 & 26 \\
\hline Business Assets & 20 & 22 & 26 & 29 & 34 & 31 \\
\hline Net Value of Vehicles & 15 & 15 & 16 & 17 & 18 & 17 \\
\hline Financial Assets & 53 & 75 & 81 & 94 & 70 & 84 \\
\hline Direct Stocks Holdings & 23 & 40 & 49 & 51 & 34 & 42 \\
\hline IRA Assets & 27 & 47 & 55 & 55 & 52 & 87 \\
\hline IRA in Stocks Value & - & - & - & - & 38 & 56 \\
\hline $\begin{array}{l}\text { IRA Plus Stocks Holdings } \\
\text { Plus DC in Stocks }\end{array}$ & - & - & - & - & 110 & 137 \\
\hline Observations & 3401 & 3401 & 2028 & 2028 & 1949 & 1949 \\
\hline
\end{tabular}

Observations with the top and bottom $1 \%$ of wealth are excluded.

The present values of Social Security wealth are calculated to be the same in real terms in the beginning and end year. See the description in Appendix 1.

We adjusted the DB values in 1994 in a similar way to the 2006 data. 
Table 2B: The Value of Components of Wealth For Members of Various HRS Cohorts Over the Period from the Second to Fourth Wave They Are in the Survey in 2010 Dollars: weighted

\begin{tabular}{|c|c|c|c|c|c|c|}
\hline \multirow[b]{2}{*}{ Source of Wealth } & \multicolumn{6}{|c|}{2010 Dollars } \\
\hline & $\begin{array}{c}\text { Original } \\
\text { HRS } \\
1994\end{array}$ & $\begin{array}{c}\text { Original } \\
\text { HRS } \\
1998\end{array}$ & $\begin{array}{c}\text { War- } \\
\text { babies } \\
2000\end{array}$ & $\begin{array}{c}\text { War- } \\
\text { babies } \\
2004\end{array}$ & $\begin{array}{c}\text { Early } \\
\text { Boomers } \\
2006\end{array}$ & $\begin{array}{c}\text { Early } \\
\text { Boomers } \\
2010\end{array}$ \\
\hline Total & $\$ 788 \mathrm{k}$ & $\$ 848 \mathrm{k}$ & $\$ 866 \mathrm{k}$ & $\$ 894 k$ & $\$ 871 \mathrm{k}$ & $\$ \$ 847 k$ \\
\hline Social Security Plus Pensions & 453 & 463 & 479 & 457 & 476 & 473 \\
\hline Social Security & 251 & 251 & 239 & 239 & 256 & 256 \\
\hline Pension Value & 201 & 213 & 240 & 218 & 220 & 218 \\
\hline DB Value & 164 & 165 & 169 & 153 & 150 & 141 \\
\hline DC Value & 37 & 48 & 71 & 65 & 70 & 77 \\
\hline Current DC Balances & 30 & 34 & 60 & 48 & 53 & 51 \\
\hline Current DC in Stocks & - & - & - & - & 33 & 25 \\
\hline Net House Value & 108 & 115 & 111 & 154 & 167 & 128 \\
\hline Real Estate & 49 & 47 & 42 & 52 & 35 & 26 \\
\hline Business Assets & 31 & 30 & 35 & 34 & 38 & 31 \\
\hline Net Value of Vehicles & 23 & 21 & 20 & 21 & 20 & 17 \\
\hline Financial Assets & 83 & 105 & 106 & 111 & 78 & 84 \\
\hline Direct Stocks Holdings & 35 & 56 & 64 & 60 & 38 & 42 \\
\hline IRA Assets & 42 & 66 & 72 & 65 & 58 & 87 \\
\hline IRA in Stocks Value & - & - & - & - & 43 & 56 \\
\hline $\begin{array}{l}\text { IRA Plus Stocks Holdings } \\
\text { Plus DC in Stocks }\end{array}$ & - & - & - & - & 123 & 137 \\
\hline Observations & 3401 & 3401 & 2028 & 2028 & 1949 & 1949 \\
\hline
\end{tabular}

